\title{
Buscando entre las cenizas
}

\author{
Instituto de Derechos Humanos de la Universidad Centroamericana \\ "José Simeón Cañas"
}

\section{Resumen}

Este artículo plasma los hechos pasados acontecidos en El Salvador, los cuales han sido deliberadamente silenciados o tergiversados debido a intereses que hasta la fecha se esconden tras la cortina de una versión oficial para reducir el margen de responsabilidad gubernamental. Asimismo rescata la verdad de la historia, donde por casi dos décadas la población vivió y sufrió las consecuencias de un conflicto social violento, con la finalidad de dejar atrás la impunidad y construir una convivencia pacífica, democrática y participativa.

"Buscas el fuego?, decía un gran rabino hasídico. Búscalo en la ceniza. Es lo que ustedes están haciendo desde el principio de este proceso; es lo que intentamos hacer desde la liberación.

Hemos buscado en la ceniza una verdad para afirmar a pesar de todo la dignidad del hombre, que no existe sino en la memoria. Gracias a este proceso, los sobrevivientes encuentran una justificación a su supervivencia.

Su testimonio cuenta, su memoria será parte de la memoria colectiva. Está claro que nada padría volver a los muertos a la vida. Pero, gracias a las palabras pronunciadas aht, el acusado no podré matar otra vez a los muertos".

(Elie Wiesel, premio Nobel de la paz y uno de los testigos en el juicio del "verdugo de Lyon", Klaus Barbie, en mayo de 1983.) 


\section{Introduccion}

Con este esfuerzo -pparte de una investigación más amplia - se pretende contribuir a impulsar el necesario rescate de la verdad acerca de la historia más reciente de El Salvador, donde por casi dos décadas la población vivió y sufrió las consecuencias de un conflicto social violento que abrió profundas y dolorosas heridas. Su pertinencia deviene de considerar que, acá, la construcción de una sociedad más justa continúa siendo una asignatura pendiente. Se trata, pues, de una reflexión que hace eco de hechos del pasado deliberadamente silenciados o tergiversados en lo sustancial, debido a intereses que hasta la fecha se esconden tras la cortina de una versión oficial. En este caso, entonces, la recuperación de la memoria histórica busca ser aportación para el cambio positivo que se requiere en aras de dejar atrás la impunidad y construir una convivencia pacífica, democrática y participativa.

Los testimonios, tablas y gráficas incluidas ilustran el período que — con toda seguridad- ha sido el más terrible en nuestra tierra. Se puede decir que, en muchas cosas, el análisis que ahora empezamos a socializar coincide con el documento final elaborado por la Comisión de la Verdad; ambos establecen los mismos patrones fundamentales de la violencia. Cualitativamente hablando también son semejantes las proporciones, por cuanto estudian la misma realidad; sin embargo, aunque las cifras que hoy se ofrecen son más elevadas, no cabe duda que ni el informe de la Comisión de la Verdad ni el recuento del IDHUCA recuperan todos los hechos que lastimosamente tuvieron lugar en esta tierra.

Actuando a la inversa, oficialmente se ha intentado ocultar o minimizar, maquillar o desvanecer lo ocurrido, con el objeto de reducir el amplio margen de responsabilidad gubemamental en los gravísimos hechos que - como política de Estado- ocurrieron en el país durante más de quince años. La negación obstinada del pasado, la tergiversación de los hechos, la equiparación de la víctima y el victimario, la evasión del castigo, la exculpación tácita o explícita del criminal - la impunidad, en una palabra - abonan la polarización social y abren las puertas al sostenimiento de la violencia, independientemente de la forma cómo se pueda manifestar en determinada etapa.
Pero, por supuesto, eso no tiene que ser inexorablemente así; del modo como se enfrente y asuma una experiencia tan traumática depende en gran medida lo que está ocurriendo hoy y lo que ocurrirá mañana. Se está, entonces, ante una disyuntiva: o la conculcación masiva e impune de los derechos fundamentales de grandes sectores de población se convierte en enfermedad recurrente, o la sociedad sana y restaña sus heridas para erradicar la costumbre de "premiar" a los altos criminales. No es posible edificar un porvenir seguro sin evocar recuerdos y sentimientos, sin dejar de aprender de las lecciones de la historia; es esa la mejor y única forma de avanzar con la garantía de que nunca más ocurrirá algo similar a lo que pasó durante ese ayer traumático.

Con este trabajo se persigue, además, que la población afectada por la violencia política y el conflicto armado encuentre elementos concretos que le permitan una participación consciente en el rescate de su memoria histórica y el reconocimiento de su honorabilidad y la de las víctimas. Busca, además, colaborar en el desarrollo de nuevas actitudes que incentiven el mayor involucramiento de la población en los asuntos públicos y coadyuven a superar, sobre bases firmes, tanto el desencanto como la frustración casi generalizados.

Ningún acto contra la dignidad humana puede considerarse asimilado y superado, mientras no se haya hecho justicia; mucho menos se puede dejar de investigar hasta aclararlo, para sólo entonces cerrar su expediente. El silencio impuesto sobre los crímenes que se cometieron en esta tierra hiere en primer lugar a quienes los padecieron y a sus seres queridos, pero igualmente constituye un atentado contra la sociedad entera. Porque tales experiencias - parte ya de la cultura e historia nacional- únicamente serán asumidas constructivamente en la medida que las y los salvadoreños seamos capaces de conocer la verdad y reconocer las distintas responsabilidades alrededor de la misma.

Con la firma del Acuerdo de Chapultepec el 16 de enero de 1992, se buscaba cerrar esa triste y lamentable etapa de la historia salvadoreña; al mismo tiempo, trataba de abrirse un repertorio de posibilidades para alcanzar la democratización del país. En esa época parecía existir cierto nivel de conciencia acerca de que la paz real, sólida y duradera sólo se lograría mediante la superación de un 
cúmulo de factores negativos que - sobre todo en materia de derechos humanos-indujeron y fomentaron la exacerbación de las pasiones y el desencadenamiento de la guerra interna.

Quizás sea muy poca la gente que desconozca que en el país —en los años setenta y ochentase cometieron graves violaciones a los derechos humanos, incontables abusos de autoridad y descomunales actos de corrupción. Sin embargo, esa desgracia global que tanto hizo sufrir al pueblo salvadoreño, aunque denunciada constantemente a nivel internacional, es todavía poco conocida en su verdadera dimensión por la opinión pública nacional. Mientras, los responsables continúan viviendo despreocupados porque fácilmente lograron evadir la justicia.

La sociedad salvadoreña no puede ni debe permanecer impasible al respecto. El "borrón y cuenta nueva" en materia de derechos humanos es inaceptable y peligroso. Inaceptable porque, al no conocer la verdad, no se aplican las sanciones correspondientes ni se cumple con una obligación legal y moral que se tiene con las víctimas y sus familiares. Peligroso porque, al imponerse, la sociedad queda en un estado de total indefensión, pues de esa manera sólo se postergan conflictos y acumulan rencores abriendo aún más las puertas al paso destructor de la violencia. Los criminales reivindican sus crímenes, sin arrepentimiento alguno, escudándose en el "deber cumplido" y dispuestos a seguir realizando lo que nunca consideraron incorrecto. Así, nunca se perdona ni se concilia nada.

De ahí que, para superar tal estado de cosas y en aras de alcanzar la necesaria armonía en el país, se debe sacar a flote la verdad y motivar la participación de la población para hacer funcionar las instituciones estatales, políticas y sociales con el fin de alcanzar justicia y establecer las condiciones racionales y civilizadas que permitan discutir en un plano distinto al actual y al del pasado buscando sinceramente resultados positivos - las formas más adecuadas para superar el estado de exclusión en el que vive tanta gente.

Los acuerdos de paz abrieron una fisura en el hasta entonces infranqueable muro de la impunidad. De ellos, la Comisión ad hoc para la depuración de la Fuerza Armada y la Comisión de la Verdad se presentaron como oportunidades únicas en el esfuerzo por transformar la compleja realidad salvadoreña. También ofrecieron herramientas singulares para entender las causas de la violencia y actuar sobre ellas, además de enfrentar eficazmente sus efectos.

El trabajo de estas instancias enormes tuvo ante sí resistencias que impidieron desarticular la inmensa maquinaria criminal que tantas vidas cobró en el pasado y que, con otras motivaciones y maneras, todavía sigue activa en la actualidad. La esencia de esas instancias coadyuvantes del proceso de pacificación, desaprovechadas de forma irresponsable, se encuentra resumida en el numeral cinco denominado "Superación de la impunidad", que apareció incluido en el primer capítulo del Acuerdo de Chapultepec; éste, a la letra dice: "Se conoce la necesidad de esclarecer y superar todo señalamiento de impunidad de oficiales de la Fuerza Armada, especialmente en casos que esté comprometido el respeto a los derechos humanos. A tal fin, las Partes remiten la consideración y resolución de este punto a la Comisión de la Verdad. Todo ello sin perjuicio del principio, que las Partes igualmente reconocen, de que hechos de esta naturaleza, independientemente del sector al que pertenecieron sus autores, deben ser objeto de la actuación ejemplarizante de los tribunales de justicia, a fin de que se aplique a quienes resulten responsables de las sanciones contempladas por la ley".

Lo anterior no se hizo y -por ello- los que planificaron, financiaron, ordenaron y ejecutaron las acciones de violencia continúan teniendo la facilidad y el poder de disponer a su antojo sobre las vidas humanas. Cabe preguntarse si lo logrado hasta ahora es suficiente para presumir ante el mundo de algo que no eliminó la impunidad; es oportuno preguntar si, además, ello garantiza un proceso sostenido que permita instaurar nuevas formas de convivencia social.

De la exacta identificación y calificación de las causas -objetivas y subjetivas-; de la determinación precisa de las responsabilidades; así como de la adecuada administración de justicia, dependerá la oportunidad de construir un futuro diferente. Lo contrario - dejar pasar esta oportunidad, que quizás sea la última - hará de esta paz no un sólido y permanente proceso de desarrollo social integral sino, apenas, el lapso entre dos guerras.

\section{Precisiones básicas}

No hay duda que los derechos humanos se han convertido en el gran tema mundial durante la se- 
gunda mitad del siglo que está por finalizar; tanto por las graves violaciones a los mismos ocurridas a lo largo y ancho del orbe como por los esfuerzos realizados para reconocerlos en las legislaciones nacionales e internacionales. La región centroamericana en general y El Salvador en particular no escapan de esa realidad: en estas tierras, por todo lo sucedido en ellas, la simple mención del término generó y genera aún sentimientos o actitudes encontradas; acá, también, se han registrado avances en la normatividad que los reconoce aunque -en la práctica - su estado continúe siendo precario.

Actualmente, quizás en su mayoría, las personas tienen alguna noción - correcta o incorrectade los derechos humanos; sus reacciones, por tanto, están condicionadas según la perspectiva particular que se tenga de los mismos: ya sea defendiéndolos o descalificándolos. Asimismo, para muchas personas - por las experiencias individuales o comunitarias vividas en el pasado- cuando se habla de ellos fluyen inmediatamente imágenes dramáticas de muerte, persecución, tortura, desapariciones forzadas, restricciones a la libertad personal o cualquier otro tipo de abusos y violencia.

En ese choque de enfoques, se ha hecho evidente -incluso ahora- la agresividad en el discurso de quienes, motivados por intereses de poder, de modo deliberado intentaron e intentan darle un carácter eminentemente político al asunto con el objeto de impedir que la población juegue un rol protagónico en el esfuerzo por su real vigencia, mediante el conocimiento más exacto de sus derechos y la utilización de los mecanismos pacíficos - judiciales y alternativos- para la solución o la transformación positiva de los conflictos. El mantener a las personas en un estado de ignorancia sobre sus derechos ha sido parte de una estrategia deliberada para sobrepasar impunemente los límites del uso legítimo del poder; el haber impedido el conocimiento o tergiversado tanto el contenido de los derechos humanos como el de los medios para su protección, ha mantenido en el silencio un gran número de las violaciones ocurridas.

Por eso hay que dejar bien claro de qué se va a hablar en este apartado. Independientemente de la manera cómo se les clasifique, entre todos los derechos humanos existe concordancia, interdependencia e indivisibilidad. Es impensable que se pretenda respetar unos y se rechacen otros: no se pue- de estar hablando, por ejemplo, de la libertad cuando se impide vivirla plenamente y expresarla; tampoco resulta aceptable que se hable de desarrollo cuando casi dos tercios de la humanidad y las generaciones venideras no encuentran en su horizonte más perspectivas que una vida en condiciones absolutamente miserables; tampoco se puede hablar de una paz verdadera cuando se le niegan verdad y justicia a las víctimas de las atrocidades cometidas en el pasado.

La Conferencia Mundial de Derechos Humanos, celebrada en Viena durante 1993, se pronunció en los siguientes términos: "Todos los derechos humanos son universales, indivisibles e interdependientes y están relacionados entre sí. La comunidad internacional debe tratar los derechos humanos en forma global y de manera justa y equitativa, en pie de igualdad y dándoles a todos el mismo peso. Debe tenerse en cuenta la importancia de las particularidades nacionales y regionales, así como de los diversos patrimonios históricos, culturales y religiosos, pero los Estados tienen el deber, sean cuales fueren sus sistemas políticos, económicos y culturales, de promover y proteger todos los derechos humanos y las libertades fundamentales".

Tanto las normas internas como los diversos convenios establecidos entre la llamada "comunidad de naciones" reconocen la existencia jurídica de los derechos humanos e imponen a los gobiernos obligaciones frente a sus ciudadanas y ciudadanos. Pero además de ese importante reconocimiento legal de todo ello, es necesario que existan y funcionen adecuadamente las instituciones ante las cuales se pueda acudir para obtener resultados favorables en caso de violaciones o amenaza de violaciones a esos derechos reconocidos. Estas instituciones son creadas en cada país y su existencia se encuentra regulada de manera precisa, destacando como garantes de los derechos humanos entre ellas el Órgano Judicial, el Ministerio Público, los cuerpos policiales y las defensorías de los habitantes o procuradurias de derechos humanos. Para estas instituciones existe el deber constitucional de vigilar el cumplimiento y respeto de los derechos y garantías fundamentales, y controlar que en condiciones de igualdad se haga justicia. La previsión, la investigación, el juzgamiento y la sanción de las violaciones a los derechos humanos son parte de ese deber.

En el marco del presente trabajo -que delimita su observación a un grupo reducido de dere- 
chos humanos pertenecientes a la llamada "primera generación": los civiles y políticos - se asumen como violación a los mismos aquella acción u omisión atribuible a agentes estatales o a particulares con su consentimiento, que atentan contra la vida, la seguridad, la integridad y la libertad de las personas. Se comete, pues, una violación cuando el Estado - de manera directa o indirectaimpide a una persona el ejercicio pleno de sus garantías constitucionales o de cualquiera de sus prerrogativas, atribuciones o libertades fundamentales. Debe quedar señalado que no se puede invocar ninguna condición especial para su-

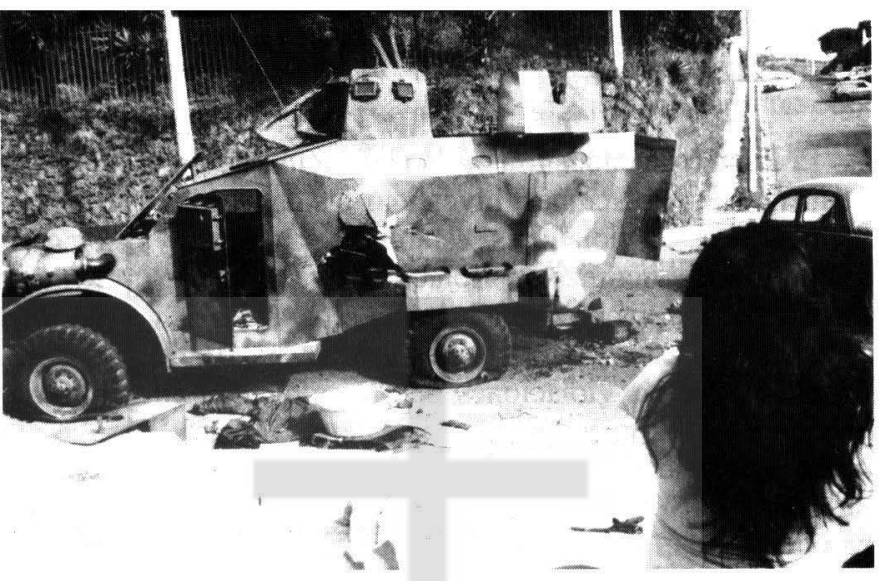
primir o violar esos derechos, ni siquiera una situación de conflicto armado; menos, aún, se pueden utilizar argumentos relacionados con opiniones políticas, participación en alguna asociación, razones religiosas, preferencias sexuales u otras manifestaciones pacíficas.

En el "Glosario de Definiciones Operacionales de las Violaciones a los Derechos Humanos", editado por la institución chilena conocida como Fundación de Ayuda Social de las Iglesias Cristianas (FASIC), se afirma: "Las violaciones a los derechos humanos son aquellos delitos que atentan contra los derechos fundamentales del hombre, en cuanto miembro de la humanidad, que se encuentran definidas en la Declaración Universal de los Derechos Humanos, y que son realizadas por el Estado directa, indirectamente o por omisión al amparo de su poder único. De esta manera, el Estado anula su finalidad esencial y provoca la inexistencia del Estado de Derecho".

Dentro del derecho internacional humanitario - llamado "Derecho de Ginebra" o derecho aplicable en la guerra - el artículo 3 común a los cuatro convenios que lo componen -invocable en conflictos armados internos - establece normas mínimas que deben ser respetadas por los contendientes en todo tiempo y lugar, prohibiendo: los atentados contra la vida y la integridad corporal, especialmente el homicidio en todas sus formas; las mutilaciones, los tratos crueles, la tortura y los suplicios; la toma de rehenes; atentados contra la dignidad personal, especialmente los tratos humillantes y degradantes; las condenas dictadas y las ejecuciones sin previo juicio ante un tribunal legítimamente constituido, con garantías judiciales re-

conocidas como indispensables por los pueblos civilizados.

En el caso de que las violaciones se produzcan en el marco de un conflicto armado interno y sean integrantes de las fuerzas alzadas en armas quienes atentan contra los derechos humanos, dichos elementos - además de quebrantar las normas del derecho aplicable en la guerra- deben ser considerados responsables frente a la legislación común del gobierno que combaten. En caso de que tales agrupaciones insurgentes lleguen a ocupar posiciones dentro del poder político, serán responsables de violaciones a los derechos humanos sólo cuando estas hayan ocurrido siendo gobiemo.

Las violaciones, pues, pueden tener diversas fuentes pero no todos los hechos de violencia llegan a configurarlas. En sentido estricto, es únicamente el poder público y sus agentes - por diversos motivos y medios - quien comete violaciones a los derechos humanos. Los particulares pueden cometer gravísimos crimenes y corresponde al Estado sancionarlos penalmente, de acuerdo con lo establecido la legislación correspondiente. En caso contrario, se vuelve cómplice en la comisión del delito.

Sin embargo, Pedro Nikken -presidente del Instituto Interamericano de Derechos Humanos y experto independiente de la ONU en El Salvador durante algunos años - afirma que "existen, desde luego, situaciones límite, especialmente en el ejercicio de la violencia política. Los grupos insurgentes armados, que controlan de una manera estable áreas territoriales o, en términos generales, ejercen de hecho autoridad sobre otras personas, poseen un germen de poder público que están obligados, lo mismo que el gobiemo regular, a mantener den- 
tro de los limites impuestos por los derechos humanos. De no hacerlo no sólo estarían violando el orden jurídico del Estado contra el que insurgen, sino también los derechos humanos".

El Estado se encuentra en la obligación de prevenir nuevas violaciones, investigar las cometidas, identificar a los violadores, establecer sanciones y asegurar a las víctimas de violaciones institucionales o a sus familiares una adecuada reparación ${ }^{1}$. Si el Estado no actúa a través de sus instituciones - de forma tal que las violaciones ocurridas quedan en la impunidad - incumple el deber de garantizar el pleno ejercicio de los derechos humanos de sus habitantes. Se entiende entonces que el Estado no sólo se obliga a respetar los derechos fundamentales y libertades democráticas, sino también a garantizar su efectiva vigencia. De esta manera, el Estado viola los derechos humanos cuando niega, impide o no realiza investigaciones para sancionar a sus agentes señalados como violadores de los derechos humanos, en virtud del derecho de garantía para con sus administrados. En este caso, es la negación de justicia la que se considera una violación grave.

Una violación a los derechos humanos, pues, puede cometerse directamente cuando el Estado no actúa en defensa de los derechos y garantías que han sido consagrados; pero, además, puede ser cometida por violación u omisión al deber de garantizarlos. El artículo 1.1. de la Convención Americana de Derechos Humanos establece el compromiso adquirido por los Estados Partes "a respetar los derechos y libertades reconocidos en ella y a garantizar su libre y pleno ejercicio a toda persona que esté sujeta a su jurisdicción, sin discriminación alguna por motivos de raza, color, sexo, idioma, religión, opiniones políticas o de cualquier otra índole, origen nacional o social, posición económica, nacimiento o cualquier otra condición social".

Dicho artículo es básico para determinar cuándo una violación a los derechos humanos reconocidos por la Convención puede ser atribuida a un Estado Parte. Con él se depositan en los Estados Partes los deberes fundamentales de respeto y garantía, de manera que todo menoscabo a los derechos humanos reconocidos en la Convención y que pueda ser atribuido a la acción u omisión de cualquier autoridad pública, constituye un hecho imputable al Estado. Así, el Estado compromete su responsabilidad en los términos previstos por la misma Convención. La primera obligación asumida por los Estados Partes en los términos del citado artículo es la de "respetar los derechos y libertades" reconocidos en la Convención. En ese marco, se debe considerar que el ejercicio de la función pública tiene límites provenientes de una realidad innegable: los derechos humanos son atributos inherentes a la dignidad humana $y$, en consecuencia, superiores al poder estatal.

La Corte Interamericana de Derechos Humanos señala, además, que "la segunda obligación de los Estados partes es la de garantizar el libre y pleno ejercicio de los derechos reconocidos en la Convención a toda persona sujeta a su jurisdicción. Esta obligación implica el deber de los Estados Partes de organizar todo el aparato gubernamental $y$, en general, todas las estructuras a través de las que se manifiesta el ejercicio del poder público, de manera tal que sean capaces de asegurar jurídicamente el libre y pleno ejercicio de los derechos humanos. Como consecuencia de esta obligación

1. Este término se usa para referirse a todos los tipos de reparación -material y moral- a las víctimas de violación a sus derechos humanos. Por ello los términos "restitución", "indemnización" y "rehabilitación" abarcan aspectos más concretos de aquélla. Ello, de acuerdo al informe de Theo van Boven, relator especial de las Naciones Unidas, elaborado como parte del "Estudio relativo al derecho de restitución, indemnización y rehabilitación a las víctimas de violaciones flagrantes de los derechos humanos y las libertades fundamentales" (E/CN.4 Sub.2/1993/8,2 de julio de 1993). 
los Estados deben prevenir, investigar y sancionar toda violación de los derechos reconocidos por la Convención y procurar, además, el restablecimiento del derecho conculcado y, en su caso, la reparación de los daños producidos por la violación de los derechos humanos".2

Y añade lo siguiente: el "Estado está en el deber jurídico de prevenir, razonablemente, las violaciones de los derechos humanos, de investigar seriamente con los medios a su alcance las violaciones que se hayan cometido dentro del ámbito de su jurisdicción a fin de identificar a los responsables, de imponerles las sanciones pertinentes $y$ de asegurar a la víctima una adecuada reparación. El deber de prevención abarca todas aquellas medidas de carácter jurídico, político, administrativo y cultural que promuevan la salvaguarda de los derechos humanos y que aseguren que las eventuales violaciones a los mismos sean efectivamente consideradas y tratadas como un hecho ilícito que, como tal, es susceptible de acarrear sanciones para quien las cometa, así como la obligación de indemnizar a las víctimas por sus consecuencias perjudiciales". ${ }^{3}$

Asimismo, afirma: "Si el aparato del Estado actúa de modo que tal violación quede impune y no se restablezca, en cuanto sea posible, a la víctima en la plenitud de sus derechos, puede afirmarse que ha incumplido el deber de garantizar su libre y pleno ejercicio a las personas sujetas a su jurisdicción. Lo mismo es válido cuando se tolere que los particulares o grupos de ellos actúen libre o impunemente en menoscabo de los derechos reconocidos en la Convención". 4

Sobre el deber de investigar las violaciones a los derechos humanos, la Corte Interamericana precisa las características del mismo: "En ciertas circunstancias, puede resultar difícil la investigación de hechos que atenten contra derechos de la persona. La de investigar es, como la de prevenir, una obligación..., debe emprenderse con seriedad y no como una simple formalidad, condenada de antemano a ser infructuosa. Debe tener un sentido y ser asumida por el Estado como un deber jurídico propio y no como una simple gestión de intereses particulares, que depende de la iniciativa procesal de la víctima o de sus familiares, o de la aportación privada de elementos probatorios, sin que la autoridad pública busque efectivamente la verdad. Esta apreciación es válida cualquiera sea el agente al cual pueda eventualmente atribuirse la violación, aún los particulares, pues, si sus hechos no son investigados con seriedad, resultarían, en cierto modo, auxiliados por el poder público, lo que comprometería la responsabilidad internacional del Estado". 5

"El deber de investigar hechos de este género advierte la Corte- subsiste mientras se mantenga la incertidumbre sobre la suerte final de la persona desaparecida. Incluso en el supuesto que circunstancias legítimas del orden jurídico interno no permitieran aplicar las sanciones correspondientes a quienes sean individualmente responsables de delitos de esta naturaleza, el derecho de los familiares de la víctima de conocer cuál fue el destino de ésta y, en su caso, dónde se encuentran sus restos, representa una justa expectativa que el Estado debe satisfacer con los medios a su alcance". 6

Cabe decir que - lamentablemente- en toda situación de tensión social o política pueden resultar víctimas de violaciones a sus derechos humanos, afectando así de manera individual $y / o$ colectiva a miembros de una sociedad. En el caso que nos ocupa destaca la violación masiva y sistemática al derecho a la vida, a la integridad física y la libertad personal; dichos derechos fueron especialmente afectados por la práctica institucional del asesinato, la tortura, la detención ilegal y la desaparición forzada de personas.

2. Sentencia Velásquez Rodríguez, del 29 de julio de 1988, párafos 166 y 167.

3. Ibid., párafos 174 y 175.

4. Ibid., párrafo 176 .

5. Ibid., párrafo 177 .

6. Ibid., párrafo 181 . 
Para determinar el concepto de víctimas, individuales y colectivas, se debe traer a cuenta lo que determina la Declaración sobre los Principios Fundamentales de Justicia para las Víctimas de Delitos y del Abuso del Poder. En ella se encuentra definido así: "Se entenderá por víctimas las personas que, individual como colectivamente, hayan sufrido daños, inclusive lesiones físicas o mentales, sufrimiento emocional, pérdida financiera o menoscabo sustancial a sus derechos fundamentales".' Para una mayor precisión, se dice lo siguiente: "En la expresión víctima se incluye además, en su caso, a los familiares o personas a cargo que tengan relación inmediata con la víctima directa y a las personas que hayan sufrido daños al intervenir para asistir a la víctima".

Por último, a fin de lograr una mejor comprensión de los elementos presentados, se considera necesario establecer el significado de "población civil", precisamente porque fue ella la que resultó más dañada por todo los hechos de violencia ocurridos en El Salvador durante muchos años: tanto por la represión estatal y la violencia política como por los abusos y las atrocidades que los ejércitos enfrentados realizaron en su contra durante el conflicto armado. Una definición concreta, lógica y que no deja lugar a dudas es la que determina la condición de persona civil por su no pertenencia a alguna de las fuerzas armadas; por ello, queda claro que: "La población civil comprende a todas las personas civiles". ${ }^{8}$ Más aún: tal como lo establece la Subcomisión de las Naciones Unidas para la Prevención de Discriminaciones y Protección de las Minorías, "las personas que no participan directamente en los combates, aunque simpaticen con los insurgentes, los acompañen, les suministren alimentos (...) conservan su carácter de población civil y por lo tanto no deben ser objeto de ataques militares".

\section{De 1975 a 1994: algunos datos de la tragedia}

A continuación se ofrece un resumen de las violaciones a los derechos humanos en El Salvador registradas, que tuvieron lugar durante el período comprendido entre 1975 y 1994, ambos años inclusive. En él aparecen cuadros y gráficos que revelan quiénes y cuántas fueron las víctimas, las modalidades de la agresión y sus responsables.
Todo ello, mediante el procesamiento de la información que fue recopilada directamente por el IDHUCA, así como de las denuncias y publicaciones hechas por la Oficina de Tutela Legal del Arzobispado (OTLA), el Socorro Jurídico Cristiano "Monseñor Óscar Romero" (SJC), la Comisión de Derechos Humanos de El Salvador (CDHES) y el Comité Cristiano Pro Desplazados de El Salvador (CRIPDES).

A partir del análisis de estos datos $\longrightarrow$ producto de un trabajo valiente, serio y fundamentado de esos organismos dedicados responsablemente a la defensa y promoción de la dignidad humana- se intenta establecer un panorama amplio en relación a los sucesos más trágicos de la historia salvadoreña, a fin de colaborar para que no vuelva a suceder algo similar.

A iniciar este apartado, se debe advertir que el cúmulo de datos incorporados en el mismo no representa la totalidad de las violaciones a los derechos humanos ocurridas en el territorio nacional a lo largo de los años examinados. Contiene tan sólo aquellas de las que se tuvo conocimiento cierto y se encuentran debidamente documentadas.

\subsection{Las violaciones}

La Comisión de la Verdad, al presentar su informe el 15 de marzo de 1993, dio cuenta de los hechos graves de violencia que logró conocer mediante "fuente indirecta"; según el documento, fueron casi 24,000. Para el desarrollo de su labor, la Comisión comprendió dentro de la mencionada "fuente indirecta" los casos que le fueron entregados por "organismos e instituciones y, por lo tanto, no fueron ratificados por una comparecencia personal"; además, en ese rubro incluyó también los casos enviados por víctimas o sus familiares sin una ratificación personal de los mismos.

A diferencia de los resultados de la Comisión de la Verdad, el producto obtenido de la investigación realizada por el IDHUCA arroja una cifra muy superior, sobre todo cuando aquella -después de haber depurado la información según sus criterios- determinó que sólo se podía hablar de 13,569 casos. Se debe considerar que el estudio hecho por el Instituto universitario abarca ocho años más que el de la Comisión —de 1975 a 1979,

7. Resolución 40/34 de la Asamblea General, ONU, 29 de noviembre de 1985.

8. Artículo 50 del Protocolo I, Adicional a los Convenios de Ginebra de 1949.

9. Resolución aprobada por consenso el 1 de septiembre de 1989 , durante el $40^{\circ}$ período de sesiones. 
al principio, y de 1992 a 1994, al final-, aunque también debe quedar claro que durante esos ocho años la cifra de casos documentados por el IDHUCA sólo es de 3,692, lo que constituye menos del $10 \%$ del total absoluto de los casos registrados a lo largo de los veinte años comprendidos en el trabajo.
En definitiva la labor que llevó a cabo el IDHUCA - tras un largo esfuerzo de cruce y depuración- arroja los siguientes resultados en lo concemiente a los casos documentados de graves violaciones a los derechos humanos y al derecho internacional humanitario en El Salvador, acaecidas durante las décadas de los setenta, ochenta y noventa.

\section{Cuadro 1}

Violaciones a los derechos humanos (casos documentados)

\begin{tabular}{|c|c|c|c|c|c|c|c|c|c|c|c|}
\hline Derechos y modos de violación & $75-76$ & $77-78$ & $79-80$ & $81-82$ & $83-84$ & $85-86$ & $87-88$ & $89-90$ & $91-92$ & $93-94$ & Total \\
\hline \multicolumn{12}{|l|}{ Derecho a la vida } \\
\hline Ejecuciones extrajudiciales & 5 & 41 & 1,897 & 1,758 & 1,197 & 501 & 336 & 242 & 519 & 704 & 7,200 \\
\hline Desapariciones forzadas & 52 & 66 & 758 & 1,650 & 919 & 466 & 592 & 615 & 134 & 1 & 5,254 \\
\hline Muertes por acciones bélicas & 2 & 0 & 196 & 312 & 447 & 343 & 33 & 106 & 2 & 0 & 1,441 \\
\hline Muertes fuera de acciones bélicas & 0 & 0 & 5 & 22 & 76 & 126 & 132 & 115 & 125 & 54 & 655 \\
\hline Subtotal & 59 & 107 & 2,856 & 3,742 & 2,639 & 1,436 & 1,093 & 1,079 & 780 & 759 & 14,550 \\
\hline \multirow{2}{*}{$\begin{array}{l}\text { Derecho a la liberted personal } \\
\text { Detención con incumplimiento } \\
\text { de formas legales } \\
\text { Otras formas de negación de } \\
\text { libertad personal }\end{array}$} & 50 & 345 & 1,516 & 2,731 & 1,790 & 2,463 & 1,608 & 2,151 & 871 & 58 & 13,593 \\
\hline & 2 & 80 & 759 & 1,321 & 889 & 1,276 & 886 & 968 & 118 & 98 & 6,397 \\
\hline Subtolal & 52 & 425 & 2.275 & 4,052 & 2.679 & 3.749 & 2.494 & 3.119 & 989 & 156 & 19.990 \\
\hline \multicolumn{12}{|l|}{ Derecho a la integridad personal } \\
\hline Torturas & 8 & 186 & 367 & 328 & 173 & 576 & 332 & 562 & 111 & 37 & 2,680 \\
\hline Penas o tratos crueles & 0 & 17 & 121 & 146 & 117 & 232 & 148 & 193 & 107 & 21 & 1,102 \\
\hline Heridos en acciones bélicas & 3 & 5 & 54 & 23 & 28 & 82 & 65 & 98 & 349 & 94 & 801 \\
\hline Heridos fuera de acciones bélicas & 1 & 0 & 13 & 6 & 3 & 18 & 44 & 30 & 70 & 53 & 438 \\
\hline Subtotal & 12 & 208 & 555 & 503 & 321 & 908 & 589 & 883 & 837 & 205 & 5,021 \\
\hline Totales & 123 & 740 & 5,686 & 8,297 & 5,639 & 6,093 & 4,176 & 5,081 & 2,606 & 1,120 & 39,561 \\
\hline
\end{tabular}

Del cuadro anterior, como puede apreciarse por las cifras, se desprende que en el período estudiado ocurrieron un total de 39,561 casos de violaciones a los derechos humanos que afectaron a la población salvadoreña. Asimismo, se observa que poco más del 50 por ciento de las mismas fueron actos contra el derecho a la libertad personal; entre los 19,990 casos de esta índole que fueron reportados, ocurrieron 13,593 (68 por ciento) detenciones con incumplimiento de las formas legales -es de- cir, aprehensiones arbitrarias e ilegales - muchas de las cuales constituyeron el primer momento de una sucesiva conculcación de otros derechos de las víctimas, incluyendo lo relacionado con su integridad - física y psicológica- y su vida.

En el mismo cuadro, también, se da cuenta de 14,550 atentados directos contra el derecho a la vida, lo que constituye cerca del 37 por ciento de los casos conocidos en los veinte años que analiza el estudio. De ellos, casi la mitad fueron resultado 
de ejecuciones arbitrarias $(7,200)$ mientras que en un 36 por ciento $(5,254)$ del total lo fueron de desapariciones forzadas.

En lo que hace al derecho a la integridad personal, los datos indican que la mayoría (53 por ciento) son casos de tortura; a ellos, les sigue un 21 por ciento de actos resultantes de la aplicación de otras penas o tratos crueles. Ambas categorías, como se observa en el cuadro referido, reúnen las tres cuartas partes del total de los 5,21 casos que fueron documentados en este rubro.

El gráfico que se ofrece a continuación muestra una dramática concentración de casos entre los años de 1980 y 1983, ambos años incluidos, destacando el primero de ellos como el de las cifras más elevadas. Se aprecia también, durante ese periodo, que la mayor cantidad de casos son por violación al derecho a la vida $(8,086)$, superando los 7,482 casos contra la libertad personal y los 1,138 ocurridos contra la integridad personal. Es posible que ello se deba, principalmente, a la aplicación de una política gubernamental marcada fundamentalmente por la intención de aniquilar físicamente la base social - real o imaginaria- de la insurgencia y de imponer, por esa vía, una macabra campaña de propaganda psicológica dirigida a hacer desistir a cualquier persona de sus inclinaciones hacia la disidencia o sus simpatías hacia la oposición de cualquier tipo.
Más adelante se observan repuntes en 1986 y 1989, pero en esos años la mayor cantidad de violaciones se dirigen contra el derecho a la libertad personal. Esto puede indicar que los tipos de violación que se utilizaban en los distintos momentos obedecían a diferentes tácticas, en el marco de una misma estrategia de contención social.

\subsection{Las víctimas}

Digna de tener presente es la información que nos ofrece el Cuadro 2, acerca de la actividad a la cual se dedicaba cada una de las víctimas. Como se aprecia, en una tercera parte del total no fue posible determinar su ocupación; en estos casos se trató de personas desconocidas que no tenían una participación directa ni indirecta en el conflicto, no detentaban cargos políticos o militares $y$, tampoco, ocupaban un lugar relevante en la vida social o económica del país. Fueron, pues, habitantes de un país sumido en la violencia; fueron personas que resultaron arrastradas por una vorágine de brutalidad que destruyó cuanto encontró en su camino. Pero - hay que dejarlo bien claro- eso no quiere decir que fueron víctimas de una fuerza ciega; más bien, lo fueron producto de una política fríamente concebida, planificada, financiada, dirigida y ejecutada que tenía al poder como su motivación fundamental: la violación de los derechos humanos elevada al rango de política de Estado y de estrategia general para la contención social.

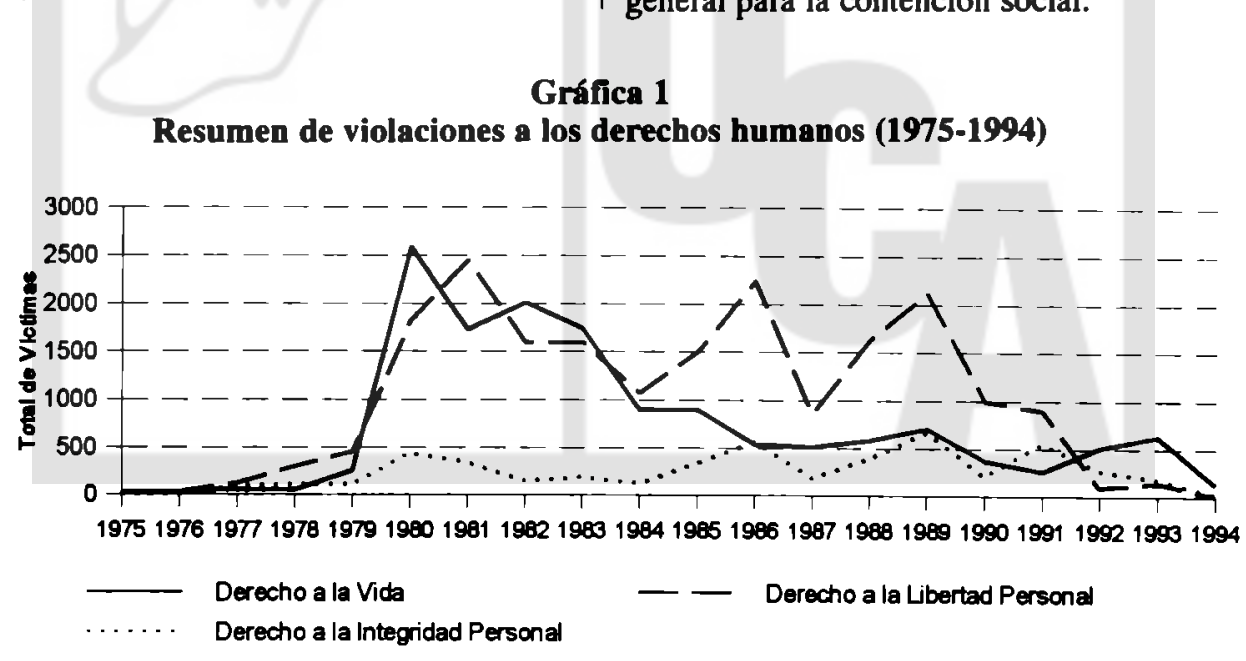


Aunque en menor medida, tal como se puede observar más adelante, también las fuerzas insurgentes - en su afán por tomar el poder por la vía armada - cargan con la responsabilidad de haber ejecutado graves hechos de violencia en contra de la población civil y acciones reñidas con las normas del derecho intemacional humanitario.

\section{Cuadro 2}

Víctimas clasificadas por ocupación

\begin{tabular}{lr}
\hline Ocupación & Cantidad \\
\hline Desconocida & 8,211 \\
Trabajador agrícola, pecuario, pesquero & 6,640 \\
Otras ocupaciones & 3,869 \\
Estudiante & 2,059 \\
Oficios varios & 1,990 \\
Actividades del hogar & 1,547 \\
Empleado privado, prestador de servicios & 1,237 \\
Comerciante & 810 \\
Profesional & 674 \\
Miembro de la Fuerza Armada gubernamental & 445 \\
Funcionario, empleado de gobierno & 328 \\
Miembro de Fuerzas de Seguridad Pública & 220 \\
Trabajador, colaborador de organización social & 92 \\
Miembro de Fuerza Armada insurgente & 75 \\
Miembro de iglesias & 74 \\
Artista y similares & 60 \\
Empresario & 11 \\
\hline Total de víctimas & 24,736 \\
\hline
\end{tabular}

cantidad de derechos que les fueron vulnerados.

En ese mismo cuadro se observa que otro grupo o sector social que resultó especialmente afectado por los elevados niveles de violencia fue el denominado "trabajadores agrícolas" -que agrupa a campesinos, jomaleros y pescadores - dentro del cual se concentra la cuarta parte de las víctimas totales; también resalta el de "estudiantes", que reúne un poco más del 8 por ciento del total de víctimas. Una posible explicación al hecho de que el grupo o sector de "trabajadores agrícolas" fuese considerado prioritario en la política de exterminio, es que tenía su lugar de vivienda en zonas altamente conflictivas $y$, por tanto, era ubicado por las fuerzas gubernamentales como "base social" de la insurgencia, además que —debido a la inaccesibilidad de muchos de los caseríos- las violaciones cometidas en ellos quedaban cubiertas más fácilmente por el manto de la impunidad. En el caso del grupo o sector de "estudiantes" la preferencia pudo haber obedecido al alto grado de participación política que tuvieron tanto los alumnos de la Universidad de El Salvador y de niveles técnicos como los de secundaria y bachillerato de diversas instituciones educativas, públicas y privadas, incluso desde antes del inicio del conflicto armado.

Los datos acumulados muestran, por otra parte, que entre las víctimas figuran también integrantes de los ejércitos gubernamental e insurgente, pero la cuantía de esas cifras es considerablemente menor que la de víctimas de la población civil no comba-

En esta parte debe anotarse que la cifra de 39,561 casos documentados que aparece en el Cuadro 1 no coincide con las 24,736 que ofrece el que se presenta en el subtítulo referido a las víctimas (Cuadro 2). Esto tiene una sencilla explicación: en no pocas ocasiones, una misma víctima fue objeto de la sucesiva conculcación de varios de sus derechos. En el primer cuadro se recogen todas las violaciones a las diferentes categorías de derechos humanos consideradas en la investigación, que fueron documentadas por las instituciones humanitarias señaladas al principio de este capítulo, independientemente de si se trata de la misma víctima. En el segundo cuadro, por su parte, se contabilizan las víctimas individuales sin tomar en consideración la

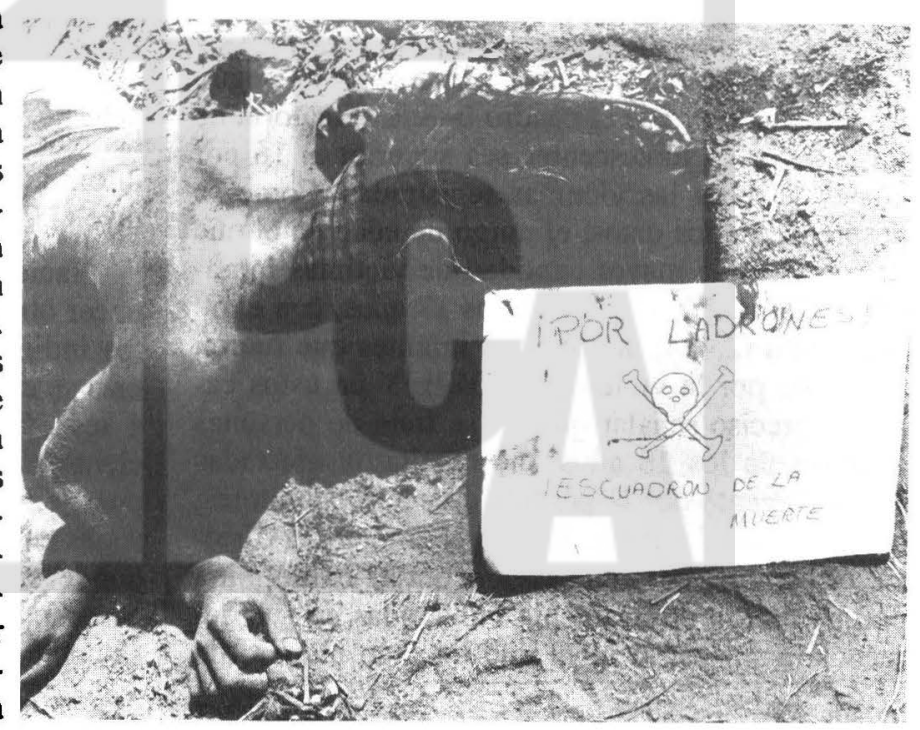


tiente. Esa situación se ilustra, por ejemplo, cuando se suma el total de combatientes de ambos bandos víctimas de uno o varios actos de violación a sus derechos (520), lo que constituye el 2.10 por ciento del gran total de víctimas y sólo se acerca al del grupo o sector de "profesionales (2.72 por ciento).

Por otra parte, para comprender de manera más acertada la amplitud de la política de exterminio social que fue concebida y ejecutada por los gobemantes salvadoreños a lo largo de esos veinte años, es importante analizar también la clasificación de las víctimas desde el punto de vista etario.

\section{Cuadro 3}

Clasificación de víctimas por edades

\begin{tabular}{lr}
\hline Rango de edad & Víctimas \\
\hline De 0 a 5 & 392 \\
De 6 a 11 & 509 \\
De 12 a 17 & 2,424 \\
Niñas, niños y adolescente de edad desconocida & 715 \\
De 18 a 23 & 5,274 \\
De 24 a 29 & 3,638 \\
De 30 a 35 & 2,425 \\
De 36 a 41 & 1,584 \\
De 42 a 47 & 1,102 \\
De 48 a 53 & 771 \\
De 54 a 59 & 479 \\
De 60 en adelante & 790 \\
Adultos de edad desconocida & 4,633 \\
\hline Total & 24,736 \\
\hline
\end{tabular}

Es notable que en términos relativos - según las cifras que ofrece el cuadro 3- la sumatoria de niñas, niños y adolescentes sea superior al 16 por ciento de todas las víctimas registradas. Como se desprende de los datos, el rango de edad en el que se concentra la mayor cantidad de víctimas infantiles es el que va de los 12 a los 17 años, con el 60 por ciento $(2,424)$ del total de infantes que fueron afectados por la violencia $(4,040)$. Y en estos casos es preciso señalar que no se trata de personas menores de los 18 años que resultaron afectadas indirectamente por la pérdida de sus progenitores, una situación de mayor empobrecimiento, la tristeza, el hambre, enfermedades o por el exilio, sino porque fueron directamente vulneradas en sus derechos humanos; al igual que un gran número de personas adultas, también sufrieron encarcelamiento y se les sometió a prácticas de tortura u otros tratos crueles e inhumanos.

En ese marco, vale la pena destacar que es alarmante la cifra de menores de edad víctimas de las violaciones más graves a los derechos humanos, como la ejecución y la desaparición forzada. De diversas maneras 1,449 niñas y niños fueron privados de sus vidas mientras otros 719 fueron detenidos y posteriormente desaparecidos por sus captores; así, sumadas ambas modalidades, se pudieron establecer 2,168 actos contra la vida (37.85 por ciento). Eso se observa en el Cuadro 4, como también es posible descubrir en él que se lograron registrar 2,796 casos de violación al derecho a la libertad personal, los cuales constituyen el $\mathbf{4 8 . 8 2}$ por ciento del total; finalmente, en relación a su integridad personal el estudio arroja 763 casos recopilados (13.32 por ciento). En total, según los resultados de la investigación, los casos documentados de violaciones cometidas en su diversas modalidades contra más de 4,000 niñas, niños y adolescentes suman 5,727.

Por otra parte, regresando al Cuadro 3, las personas adultas comprendidas entre las edades que van de los 18 a los 23 años fueron las que -con más frecuencia- aparecieron entre las víctimas de la violencia política y bélica, sumando 5,274 (25.48 por ciento), de un total de 20,696 personas mayores de 18 años que se vieron afectadas directamente. Siguen, en orden decreciente, los rangos de 24 a 29 años con 3,638 (17.57 por ciento); de 30 a 35 años de edad con 2,425 (11.72 por ciento); 1,584 personas ( 7.65 por ciento) de 36 a 41 años; y 1,102 (5.32 por ciento) de 42 a 47. Los casos de las personas adultas cuya edad no aparecía en la información recabada suman 4,633 , lo que constituye el 22.39 por ciento del total.

Haciendo una acumulación con objeto de conocer otros efectos de la violencia, los mismos datos indican que la concentración mayor de víctimas se encuentra en un rango que va desde los 18 a los 35 años de edad, hasta alcanzar 45.8 por ciento del gran total $(24,736)$. De esa manera, pues, en ese rango se encuentran ubicadas las personas en plenitud de sus facultades productivas, de donde se deduce que con la vulneración de sus derechos se produjo un daño adicional al país en su conjunto. 


\section{Cuadro 4}

Violaciones cometidas contra menores de edad (casos documentados)

\begin{tabular}{|c|c|c|c|}
\hline Modalidades de violación & Niños & Niñas & Total \\
\hline $\begin{array}{l}\text { (A) derecho a la vida } \\
\text { Privación arbitraria de la vida } \\
\text { Ejecución } \\
\text { Ejecución sumaria } \\
\text { Ejecución extrajudicial } \\
\text { Desaparición forzada } \\
\text { Muerte por acción bélica } \\
\text { Muerte por otro tipo de acción } \\
\text { Muerte por explosión de granada } \\
\text { Muerte por explosión de mina } \\
\text { Muerte por explosión de bomba } \\
\text { Muerte por fusil } \\
\text { Muerte por ametralladora } \\
\text { Muerte por ataque a concentración } \\
\text { Muerte por atentado }\end{array}$ & $\begin{array}{r}129 \\
1 \\
1 \\
429 \\
540 \\
226 \\
10 \\
55 \\
46 \\
21 \\
5 \\
7 \\
1 \\
2\end{array}$ & $\begin{array}{r}25 \\
1 \\
0 \\
231 \\
179 \\
200 \\
3 \\
18 \\
11 \\
19 \\
5 \\
1 \\
1 \\
1\end{array}$ & $\begin{array}{r}154 \\
2 \\
1 \\
660 \\
719 \\
426 \\
13 \\
73 \\
57 \\
40 \\
10 \\
8 \\
2 \\
3\end{array}$ \\
\hline $\begin{array}{l}\text { (B) derecho a la integridad personal } \\
\text { Torturas } \\
\text { Tortura } \\
\text { Tortura física } \\
\text { Agresión sexual } \\
\text { Violación propia } \\
\text { Casligo corporal } \\
\text { Descarga eléctrica } \\
\text { Golpes } \\
\text { Corte y/o pinchazo } \\
\text { Colgamiento } \\
\text { Quemadura } \\
\text { Heridas } \\
\text { Negación de alimento } \\
\text { Tortura psicologica } \\
\text { Aislamiento } \\
\text { Incomunicación } \\
\text { Insulto } \\
\text { Amenaza } \\
\text { Of́r olra tortura } \\
\text { Simulacro de ejecución } \\
\text { Penas o tratos crueles } \\
\text { Penas o tratos crueles en la detención } \\
\text { Penas o tratos crueles al momento de la detención } \\
\text { Penas o tratos crueles sin detención } \\
\text { Lesión } \\
\text { Lesión en acción belica } \\
\text { Lesión en ataque a concentración } \\
\text { Lesión en atentado } \\
\text { Lesión en otro tipo de acción } \\
\text { Lesión por explosión de granada } \\
\text { Lesión por explosión de mina } \\
\text { Lesión por explosión de bomba } \\
\text { Lesión por ama corta } \\
\text { Lesión por fusil } \\
\text { Lesión por ametralladora } \\
\text { al }\end{array}$ & $\begin{array}{r}15 \\
34 \\
4 \\
0 \\
6 \\
2 \\
46 \\
4 \\
3 \\
4 \\
3 \\
3 \\
6 \\
1 \\
1 \\
0 \\
12 \\
1 \\
1 \\
\\
20 \\
67 \\
41 \\
4 \\
38 \\
19 \\
9 \\
18 \\
117 \\
3 \\
3 \\
4 \\
3 \\
6\end{array}$ & $\begin{array}{r}12 \\
6 \\
38 \\
9 \\
2 \\
2 \\
18 \\
6 \\
0 \\
0 \\
1 \\
2 \\
4 \\
0 \\
1 \\
1 \\
11 \\
0 \\
1 \\
7 \\
17 \\
33 \\
1 \\
19 \\
7 \\
5 \\
9 \\
40 \\
4 \\
0 \\
2 \\
6 \\
1\end{array}$ & $\begin{array}{r}27 \\
40 \\
42 \\
9 \\
8 \\
4 \\
64 \\
10 \\
3 \\
4 \\
4 \\
5 \\
10 \\
1 \\
2 \\
1 \\
23 \\
1 \\
2 \\
\\
27 \\
84 \\
74 \\
5 \\
57 \\
26 \\
14 \\
27 \\
157 \\
7 \\
3 \\
6 \\
9 \\
7\end{array}$ \\
\hline $\begin{array}{l}\text { (C) derecho a la libertad personal } \\
\text { Privación ilegal de la libertad } \\
\text { Detención con incumplimiento de formas legales } \\
\text { Secuestro } \\
\text { Reclutamiento forzoso } \\
\text { Derecho a la seguridad personal } \\
\text { Amedrentamiento } \\
\text { Amenaza } \\
\text { Allanamiento } \\
\text { Cateo }\end{array}$ & $\begin{array}{r}8 \\
1,393 \\
9 \\
31 \\
5 \\
107 \\
48 \\
376 \\
56\end{array}$ & $\begin{array}{r}4 \\
483 \\
6 \\
0 \\
3 \\
71 \\
15 \\
157 \\
24\end{array}$ & $\begin{array}{r}12 \\
1,876 \\
15 \\
31 \\
8 \\
178 \\
63 \\
533 \\
80\end{array}$ \\
\hline Total & 4,004 & 1,723 & 5,727 \\
\hline
\end{tabular}




\subsection{Los responsables}

Parafraseando el título del documento que hace unos años presentó Leo Valladares Lanza - Comisionado Nacional de los Derechos Humanos de la República de Honduras - para establecer la verdad sobre las desapariciones forzadas que ocu- rrieron en el país vecino durante la década de los ochenta, esta parte de la investigación sobre los dolorosos sucesos acaecidos en El Salvador entre 1975 y 1994 debe iniciarse reafirmando que los hechos hablan por sí mismos. Por eso, de entrada, se presenta lo que sigue.

\section{Cuadro 5 \\ Responsables según derecho violado}

\begin{tabular}{lrccrc}
\hline Hechor & A la vida & A la libertad personal & A la integridad personal & Totales & $\%$ \\
\hline Fuerza armada de El Salvador & 3,250 & 5,336 & 1,186 & 9,772 & 24.70 \\
Fuerzas combinadas (gobierno) & 1,990 & 5.565 & 1,429 & 8,301 & 20.98 \\
Cuerpos de Seguridad Pública & 1,214 & 4,882 & 1,381 & $\mathbf{8 , 1 6 0}$ & 20.63 \\
Grupos paramilitares & 3,924 & 2,694 & 505 & 7,123 & 18.01 \\
Desconocido & 3,195 & 352 & 429 & 3,976 & 10.05 \\
Fuerzas insurgentes & 957 & 1,094 & 58 & 2,109 & 5.33 \\
Gobierno local, municipal & 20 & 67 & 33 & 120 & 0.30 \\
\hline Totales & 14,550 & 19,990 & 5,021 & 39,561 & 100 \\
\hline
\end{tabular}

Gráficamente, los niveles de responsabilidad se observan así:

\section{Gráfica 2}

Responsables de violaciones a los derechos humanos (1975-1994)

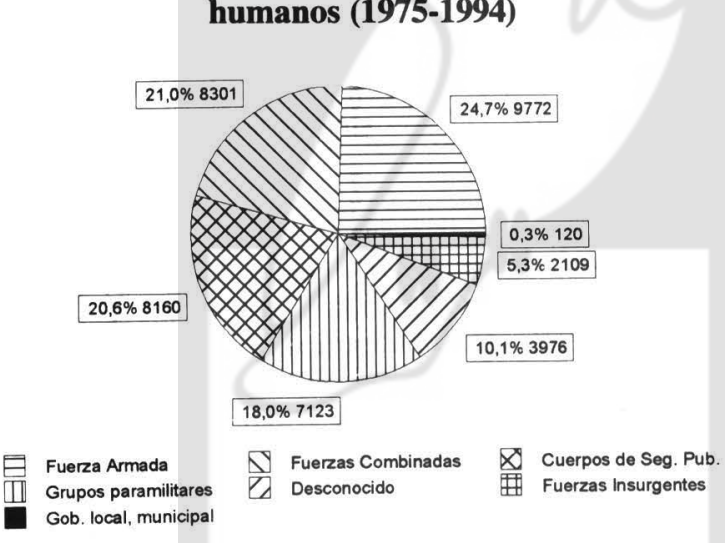

Cuando se estudian detenidamente los datos que aparecen en el cuadro anterior, se puede apreciar que - rubro por rubro- es en los agentes estatales sobre los que recae el mayor grado de responsabilidad en relación a los hechos que, a lo largo de veinte años, tuvieron lugar en El Salvador y fueron denunciados ante los organismos humanitarios apuntados antes. ¿Por qué se hace esa aseveración? Porque sólo al sumar las violaciones atribuidas a la Fuerza Armada de El Salvador
(FAES), a los Cuerpos de Seguridad Pública y a las llamadas "fuerzas combinadas" (militares, policías y guardias) la cifra es de 26,233 hechos que en conjunto representan el 66.31 por ciento del gran total registrado.

Y si, además, se considera que los "grupos paramilitares" estaban integrados por elementos asimilados a las estructuras oficiales a través de diversos organismos - Organización Democrática Nacionalista (ORDEN), "defensas civiles" y "comisionados militares", entre otros- y que a ellos se les señala como ejecutores de 7,183 violaciones, el nivel de responsabilidad gubemamental asciende a un 84.47 por ciento ( 33,416 hechos).

De igual manera, debe precisarse que el autor material ubicado tras los anteriores con mayor frecuencia es el que se denomina "hechor desconocido". En este punto, no ha sido difícil detectar en los testimonios la conexión existente entre las estructuras criminales y los círculos oficiales, tanto por el modus operandi como por las circunstancias que rodearon los hechos y la impunidad reinante en la mayor parte de sus actos criminales. Aún más: en muchos casos fue posible encontrar vínculos entre los grupos de sicarios - aparentemente independientes- y jefes militares o policiales, así como dirigentes políticos del grupo gobernante o individuos pertenecientes a prominentes familias de enormes recursos económicos. 
Algunos de estos grupos solían identificarse con nombres que indicaban con toda claridad su inclinación ideológica y su adhesión política; popularmente se les conocía de manera genérica como "escuadrones de la muerte". Como se observa en los cuadros que siguen, resulta notable la participación de esos "escuadrones de la muerte" en las acciones donde la saña de los criminales reflejaba, con toda nitidez, que obedecían la orden de defender el poder a toda costa y dejar sentado un ejemplo de terror para inhibir la participación ciudadana en la lucha política para modificar el estado de cosas en la sociedad salvadoreña. Por citar algo: a ellos se atribuye el 28 por ciento de las desapariciones forzadas, alcanzando de esa forma el primer sitio de la responsabilidad en esa categoría.

\section{Cuadro 6}

Responsabilidad en las desapariciones forzadas de 1975 a 1994

\begin{tabular}{lr}
\hline Hechor & Hechos \\
\hline Desconocido & 1,462 \\
Fuerza Armada de El Salvador & 1,067 \\
Grupos paramilitares & 1,016 \\
Cuerpos de Seguridad Pública & 708 \\
Fuerzas combinadas (gobiemo) & 504 \\
Fuerzas insurgentes & 483 \\
Gobierno local, municipal & 14 \\
\hline Total & 5,254 \\
\hline
\end{tabular}

Lo anterior, visto gráficamente, se presenta de la siguiente manera:

Gráfica 3

Desapariciones forzadas clasificadas por responsables (1975-1994)

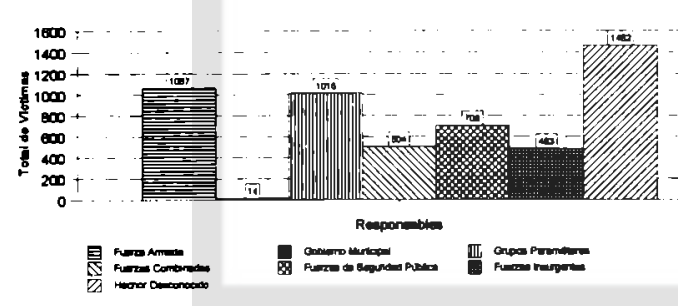

Asimismo, los llamados "escuadrones de la muerte" provocaron durante esos veinte años el 18.8 por ciento de las ejecuciones extrajudiciales denunciadas, para situarse en el segundo sitio más alto dentro de esa modalidad de barbarie sólo debajo de los "grupos paramilitares" (39.05 por ciento). Eso se concluye al observar lo que sigue.

\section{Cuadro 7}

Responsabilidad en las ejecuciones extrajudiciales de 1975 a 1994

\begin{tabular}{lr}
\hline Hechor & Hechos \\
\hline Grupos paramilitares & 2,812 \\
Desconocido & 1,359 \\
Fuerza Armada de El Salvador & 1,219 \\
Fuerzas combinadas (gobierno) & 1,035 \\
Cuerpos de Seguridad Pública & 473 \\
Fuerzas insurgentes & 297 \\
Gobierno local, municipal & 5 \\
\hline Total & 7,200 \\
\hline
\end{tabular}

Los ejemplos anteriores, nos llevan a concluir que esas organizaciones criminales denominadas "escuadrones de la muerte" tuvieron como su principal razón de existir —en el marco de esos veinte años- la coadyuvancia en el mantenimiento de una situación desfavorable para la mayoría de la población en lo económico, social y político mediante la realización del "trabajo" contrainsurgente más sucio, injustificable e ilegítimo. Para el cumplimiento de sus objetivos, dichos grupos armados ilegales actuaron contando con el amparo directo o indirecto del Estado; más aún: se sabe que sus integrantes provenían en un buen número de las filas castrenses y de las diferentes corporaciones policiacas, bajo la dirección de oficiales militares.

La Comisión de la Verdad, por su lado, calificó a los "escuadrones de la muerte" como un "infame fenómeno" ligado a la estructura formal del Estado, por acción u omisión. "Muchas de las autoridades civiles y militares - dice el informe de la Comisión- que actuaron durante los años ochenta, participaron, promovieron y toleraron la actuación de estos grupos". Más adelante, el documento refiere que "dos casos ilustran la composición y actuación de los escuadrones...: el grupo alrededor del Mayor D’Aubuisson y los escuadrones que actuaban desde las secciones de inteligencia de las instituciones militares...". Aunque, precisa, éstos no fueron los únicos escuadrones de la muerte que actuaron en el país. Una suerte de connivencia establecida entre empresarios, terratenientes, militares, fuerzas de inteligencia y seguridad dio vida a otros grupos de sicarios que -al 
igual que aquéllos - también contaron con la tolerancia oficial.

En el siguiente escalón de la responsabilidad en los hechos ocurridos de 1975 a 1994 y denunciados ante los organismos humanitarios incluidos en el presente estudio, se encuentran ubicadas las "fuerzas insurgentes". A ellos se atribuye la realización del 5.33 por ciento de todos los casos; ese porcentaje, quizás, pudo haberse incrementado de no haber existido una campaña gubernamental permanente que ligaba — sin distinción alguna- a todos los espacios de la sociedad desde donde se defendían los derechos humanos con estructuras orgánicas de alguna organización del Frente Farabundo Martí para la Liberación Nacional (FMLN) o con todo el Frente en general. De las graves violaciones registradas, destacan las que iban contra la libertad de las personas a partir de dos prácticas desarrolladas a lo largo de esos años: la de los secuestros -extorsivos y/o políticos-y la del reclutamiento forzado. En segundo lugar, se encuentran las violaciones al derecho a la vida, principalmente mediante la realización de los llamados "ajusticiamientos" que —en la realidaderan simples ejecuciones extrajudiciales igualmente condenables.

Queda, en el último lugar, la responsabilidad de los "gobiemos locales, municipales". Al observar el total de casos que les son atribuidos a éstos -únicamente 120 - surge una elemental reflexión: esos pocos testimonios de las víctimas y sus familiares acusándolos, son clara materialización de una política pensada y realizada desde un poder centralizado, y no la sucesión de miles y miles de incontrolables hechos de violencia ejecutados por bandas de sicarios locales o elementos de tropa que actuaban arbitrariamente cometiendo excesos.

\section{Modalidades más frecuentes de la violencia}

A continuación se presentan, de manera puntual, las características principales ubicadas dentro de las prácticas sistemáticas más graves de violación a los derechos humanos, según el estudio de casos en el desarrollo de la investigación.

\subsection{Síntesis del modus operandi en las ejecucio- nes extrajudiciales selectivas con participa- ción de la Fuerza Armada}

(a) En general, las acciones directas de ejecuciones extrajudiciales —hayan sido éstas precedi- das o no por campañas difamatorias contra las víctimas o los grupos a los que pertenecían - se daban en un marco de represión y amedrentamiento hacia los sectores y grupos sociales de personas consideradas opositoras al régimen y a la Fuerza Armada.

(b) Las personas ejecutadas eran, en muchos casos, conocidos líderes de sus respectivos sectores u organizaciones sociales y, como tal, considerados "objetivos militares". Por las condiciones en que se realizaban las ejecuciones, se desprende que las víctimas -individual o colectivamenteeran sometidas a investigaciones sobre su persona y fueron objeto de seguimiento por un tiempo, corto o de mayor duración, con el fin de establecer o determinar sus movimientos, lugares frecuentados, domicilio y trabajo así como para ubicar a las personas que integraban su círculo familiar, laboral y social. Todo ello, para definir el mejor momento y la manera más idónea para actuar.

(c) En los casos examinados, dadas las características de las ejecuciones y la calidad - tanto personal como social- de las víctimas, la orden para la realización de cada operativo tuvo que ser dada por uno o varios oficiales de alto rango a partir de un plan que incluía el encubrimiento, por acción u omisión, del resto de la alta jerarquía militar.

(d) En la generalidad de las violaciones del derecho a la vida, a la hora de realizar los operativos actuaban fuerzas combinadas; es decir, de diferentes unidades y ramas de la FAES con efectivos paramilitares y - de ser necesario- elementos de los cuerpos de seguridad, ya sea para confundir e impedir su identificación precisa o simplemente como refuerzo de la unidad principal que ejecutaba la acción. Pero cuando se trataba de ejecuciones extrajudiciales selectivas, éstas eran realizadas por un grupo reducido de elementos generalmente preseleccionado por ser el más idóneo para ejecutarlas.

(e) Se proporcionaba un encubrimiento institucional, desde el oficial de más alto rango involucrado hasta la tropa misma que ejecutaba la operación. De igual manera, se utilizaban los medios masivos de difusión para anular o desmentir cualquier otra versión contraria a la oficialmente dada.

(f) Del conjunto de los casos de ejecuciones extrajudiciales selectivas que ocurrieron en El Salvador, son muy pocos los que cuentan con una mínima investigación judicial y policial realizada. 
Sólo en algunos de ellos, por circunstancias especiales como en los "caso jesuitas" o en el del ciudadano suizo Jürg Weis, se lograron algunos avances. Por lo general las investigaciones de las instituciones estatales, incluyendo las realizadas en los casos antes referidos, tenían limitaciones y restricciones semejantes que iban desde las actitudes negligentes hasta el esfuerzo para el total encubrimiento. Destaca el "caso jesuitas", dentro del cual - pese a ciertos resultados y no obstante las condiciones favorables para el desarrollo de una buena investigación- se observaron graves fallas que afectaron seriamente la posibilidad de conocer toda la verdad, independientemente de que la misma se haya revelado por otros medios.

(g) En ambos casos -el de Weis y el de los sacerdotes- las averiguaciones realizadas por la Comisión de Investigación de Hechos Delictivos (CIHD), se limitaron sólo a las diligencias formales básicas pero insuficientes. No se intentó, en ningún momento, identificar a los últimos responsables de éstos. Por el contrario, se realizaron las experticias convenientes para confirmar -de cualquier manera - la versión sostenida por la institución castrense y el gobiemo; cualquier otra diligencia que de realizarse hubiera conducido a desmentir las explicaciones oficiales, fue evitada o cumplida parcial y deficientemente.

(h) En general, los respectivos jueces de las causas no profundizaban en el análisis crítico del deficiente trabajo de investigación por la CIHD; tampoco se molestaban en cuestionar a sus integrantes por actuar incorrectamente. Ni los primeros ni la segunda se interesaban por adentrarse en los elementos claves para buscar, de forma seria y profesional, la verdad completa de los actos violatorios que conocían. Las acciones del sistema judicial eran nulas o casi nulas $y$, en algunos casos, se limitaban a trabajar con las pocas variables que la CIHD u otros órganos auxiliares le ofrecían. En conjunto, era evidente la manipulación del sistema judicial por parte de la institución castrense al volverlo pieza del esquema de encubrimiento e impunidad de sus miembros, convirtiéndolo así en un importante elemento del modus

operandi aplicado para cometer este tipo de violaciones a los derechos humanos.

\subsection{Síntesis del modus operandi en las torturas - los tratos crueles, inhumanos y degra- dantes}

(a) Invariablemente, las capturas se realizaban sin orden judicial escrita al igual que los cateos a locales de organizaciones consideradas como opositoras al gobiemo. En muchas ocasiones, las llevaban a cabo agentes vestidos de civil fuertemente armados que no se identificaban; las personas detenidas no eran informadas, al momento de su captura, sobre los cargos que se les imputaban.

(b) Muchas veces, las víctimas eran introducidas violentamente a vehículos sin identificación alguna. Al introducirlos a éstos, eran vendadas y amarradas o lanzadas al piso para evitar que supieran el rumbo hacia donde las conducían. Tanto al momento de la captura como en el traslado al lugar de detención, las personas detenidas eran objeto de amenazas y violencia física.

(c) Invariablemente, al entrar en los lugares de detención las víctimas continuaban vendadas y amarradas. Se les colocaba en celdas aisladas, por lo general con fuerte aire acondicionado. Casi desde ese instante comenzaban las torturas físicas y continuaban las psicológicas, así como otro tipo de maltratos (ver Cuadro 4). Esta situación se mantenía invariable, prácticamente durante toda la detención administrativa. 
(d) Las torturas y los malos tratos se utilizaban para obtener confesiones extrajudiciales, buscar información o para usar al detenido con fines de propaganda.

(e) Si la detención la realizaban elementos de la Fuerza Armada, por lo general la víctima era trasladada a instalaciones de los cuerpos de seguridad u "órganos auxiliares de la administración de justicia", porque eran las únicas instancias facultadas para recibir declaraciones extrajudiciales válidas; aunque no faltaron ocasiones en que las diligencias realizadas por la institución castrense fueron contempladas como pruebas en los tribunales.

(f) Al cabo de la detención administrativa -72 horas o hasta quince días bajo régimen de excepción-, la víctima era liberada o consignada a la orden de los tribunales competentes, generalmente bajo la amenaza de no denunciar los vejámenes sufridos.

(g) El tribunal estaba en la obligación de tomarle declaración indagatoria al imputado. Esa era básicamente la única oportunidad de negar los cargos consignados en la confesión extrajudicial. Muchas personas que eran liberadas o que continuaban detenidas denunciaban ante la autoridad judicial las torturas y los malos tratos a los que habian sido sometidas, pero la investigación de ésta se limitaba a recibir la "declaración de ofendido" y ordenar el reconocimiento médico. Aunque se descubriesen secuelas y señales de tortura, no se hacía más. En la investigación no se conoció de algún expediente judicial abierto o la existencia de un imputado por haber torturado o maltratado a personas detenidas; tampoco se encontraron investigaciones policiales, aunque el propio representante especial de la Comisión de Derechos Humanos de las Naciones Unidas presentaba algunos casos en su informe anual. Cuando personas u organizaciones e instituciones civiles de derechos humanos denunciaban tales hechos, la reacción de las autoridades civiles y militares era atribuir las acusaciones a una "campaña de desprestigio contra la Fuerza Armada, orquestada por el FMLN y sus organismos de fachada». La impunidad y el encubrimiento eran absolutos.

(h) En la mayoría de casos, la confesión extrajudicial era la única "prueba". Para ello, bastaba que fuese corroborada en términos generales por dos testigos que invariablemente pertenecían a las mismas estructuras represivas. Sobre esa "base", se ordenaban detenciones provisionales que se prolongaban por meses y hasta años sin una decisión judicial sobre el fondo de los hechos. Nadie investigó o sancionó la extrema retardación de justicia ni se dispusieron medidas para evitarla.

(i) La incomunicación de las personas durante su detención administrativa, nulificaba el derecho de defensa. Además, en la primera etapa del proceso judicial, no existía obligación jurídica de proporcionar al imputado defensor de oficio, por lo cual podía pasar mucho tiempo sin que pudiese tener una defensa garantizada y adecuada. Durante los primeros años de la década de los ochenta, bajo la vigencia del decreto 507 , la situación era mucho más grave pues se establecía un período de seis meses sin intervención de defensor y con tramitación secreta del procedimiento.

\subsection{Síntesis del modus operandi en las desapa- riciones forzadas}

(a) La detención de las víctimas se producía en un marco de generalizadas violaciones a los derechos humanos contra de opositores reales o supuestos al gobiemo. Su participación en actividades políticas o gremiales las hacía sospechosas de pertenecer a estructuras de la insurgencia $y$, por tanto, se convertían en objeto de acciones represivas.

(b) Las víctimas eran objeto de un seguimiento previo. La forma de la detención indica que los captores sabían cuándo y cómo actuar de la manera más adecuada, ya sea para no ser identificados o para lograr un efecto psicológico de terror e inhibición entre familiares o compañeros de actividades.

(c) Cuando la detención era realizada de manera abierta, a plena luz del día y en un lugar transitado, los hechores no se preocupaban por observación 0 acción alguna de autoridades policiales o militares.

(d) Por lo regular, los captores iban vestidos de civil y fuertemente armados, en vehículos polarizado, sin placas ni otras señales que permitiesen identificarlos fácilmente. Las víctimas eran detenidas con lujo de violencia, introducidas al vehículo y trasladadas con rumbo desconocido. De acuerdo con los casos examinados, si las víctimas no eran ejecutadas inmediatamente, eran conducidas a cárceles clandestinas o instalaciones estatales policiales o militares. 
(e) Pese a no conocer con exactitud lo sucedido después con las víctimas, en la mayoría de los casos existe una razonable presunción de que fueron asesinadas. En algunos casos, se pudo comprobar que los cadáveres eran enterrados clandestinamente, lanzados a carreteras desde vehículos en marcha o arrojados desde el aire a zonas de difícil acceso. En el mismo sentido, casi siempre las víctimas eran objeto de torturas o tratos crueles, inhumanos y degradantes.

(f) Si bien las investigaciones de los familiares y de las organizaciones e instituciones civiles de derechos humanos racionalmente indicaban responsabilidad de agentes estatales, militares o policiales, la detención de las víctimas era negada repetidas veces incluso a los jueces ejecutores cuando funcionaba el recurso de exhibición personal. Las autoridades militares y policiales nunca reconocían las capturas y aseguraban que las denuncias eran parte de una campaña difamatoria contra la Fuerza Armada y el gobiemo.

(g) La Fiscalía General de la República y las autoridades judiciales no hacían absolutamente nada, a pesar de las reiteradas publicaciones en los medios de comunicación y las campañas nacionales e intemacionales de denuncia sobre la desaparición forzada de numerosas personas en El Salvador.

\subsection{Síntesis del modus operandi en operaciones militares efectuadas contra la población ci- vil, dentro de las zonas conflictivas}

(a) La tropa a cargo de realizar la operación fuera ésta de pequeña, mediana o gran envergadura- se componía generalmente de efectivos combinados de la Fuerza Armada (batallones élites, infantería, artillería y aviación), de los cuerpos de seguridad, y elementos paramilitares, según las necesidades y otras circunstancias.

(b) El objetivo militar específico era la población civil.

(c) Los operativos se realizaban contra grupos humanos consideradas por la FAES como bases de apoyo a la insurgencia, ubicadas regularmente dentro de las zonas conflictivas y bajo control insurgente.

(d) La tropa que realizaba las operaciones era transportada por aire, en muchos casos desde bases militares específicas u otros lugares cercanos a la zona donde se realizaba el operativo. (e) En la mayoría de los casos, las operaciones se iniciaban con el lanzamiento masivo de bombas, morteros y otros artefactos explosivos junto al ametrallamiento directo o muy cercano contra las poblaciones, mediante la utilización de recursos aéreos y artilleros. El ataque aéreo o de artillería, en muchas ocasiones sirvió para el "ablandamiento" previo en la zona y/o de refuerzo directo para el ataque de la tropa de infantería que realizaba las acciones en tierra. Desde ese momento, se comenzaban a causar enormes pérdidas materiales y humanas entre la población civil.

(f) En ciertos casos, luego del desembarco, la población civil entera de un determinado lugar era concentrada en algún sitio para someter a sus miembros - de manera individual o colectiva, sin consideración de alguna de sexo, edad o limitación física- diversos tratos crueles, inhumanos y degradantes e incluso a formas de tortura. Después, bajo órdenes del oficial jefe del operativo, se procedía a seleccionar personas para someterlos a torturas y tratos más graves, antes de asesinarlos con evidentes muestras de sadismo y con el obvio propósito de atemorizar al resto de los habitantes de la manera más arbitraria. Para ello, en no pocas ocasiones, se utilizaban listas previamente elaboradas a partir de datos obtenidos a través de informantes dentro de las localidades.

(g) En otros casos, apenas desembarcada y sin mediar palabras, la tropa que participaba en el operativo disparaba directa e indiscriminadamente a la población y organizaba emboscadas para atrapar a las personas que huían. Los soldados cercaban a la población con el fin de hacerles imposible la huida. En algunos casos, el cerco era cerrado con la misma tropa y, en otras oportunidades, con el paso de algún río de la zona u otro tipo de barrera natural.

(h) En los casos referidos en el literal precedente, los efectivos militares se ensañaban con la población civil desamada e indefensa, lo que se desprende de los relatos hechos por los sobrevivientes de las matanzas en los que se describe cómo niñas y niños, personas adultas mayores, mujeres y hombres eran atrozmente vejados. Ejemplo de lo anterior es una de las formas de asesinar a mujeres embarazadas, cuando les abrían el vientre y les extraían sus fetos. Con todo ello, se hacía más evidente la existencia de órdenes para que no quedaran sobrevivientes. 
erativos contemplaban, además del J físico de las personas, la destrucción de los bienes materiales de las poblaciones a las que incursionaban las tropas, incluyendo a los animales para el trabajo y la alimentación. Hasta entonces se daban por concluidos.

(j) No se realizaba investigación judicial de oficio ni a petición de parte en ninguno de estos casos. Tampoco se llevaba a cabo investigación administrativa al respecto dentro de la institución castrense. Se trataba de la completa abdicación de todas las obligaciones del Estado en materia de derechos humanos y del control más absoluto de los militares sobre los mecanismos estatales más idóneos al respecto.

(k) Estas matanzas eran ignoradas por los medios de masivos de difusión dentro del país o, cuando no podían pasar desapercibidas, se presentaban como muertes producto de "fuego cruzado" entre los bandos armados o realizadas por el FMLN; en última instancia, se informaba falsamente que se trataba de miembros activos del FMLN.

\section{Análisis de la responsabilidad militar en la violación a los derechos humanos y al dere- cho internacional humanitario}

Resulta evidente la participación institucional en las graves violaciones a los derechos humanos ocurridas a lo largo de los veinte años examinados. La misma Proclama de la Fuerza Armada, elaborada en octubre de 1979, reconoció que sus efectivos habían cometido múltiples abusos contra los derechos y libertades fundamentales de la población; y -en honor a la verdad, tal como lo revelan los datos proporcionados antes- se debe decir que durante los trece años siguientes su comportamiento empeoró.

La prensa nacional e intemacional señaló, en múltiples ocasiones, la participación de efectivos militares en hechos de violencia. De igual forma, los archivos de las organizaciones civiles de derechos humanos nacionales e intemacionales y de los organismos intergubernamentales especializados en la materia, están llenos de denuncias e investigaciones sobre violaciones imputadas a la Fuerza Armada, muchas de las cuales llegaron a manos de la Comisión de la Verdad que las corroboró por sus medios.

La cuestión no es, pues, si existieron esas violaciones; existieron. De lo que se trata es de que quede claro que no fueron actos puntuales y esporádicos ni mucho menos - como algunos se atreven a afirmar - hechos gloriosos que salvaron a la Patria. Por el contrario, fueron aciones ilegales realizadas sistemáticamente en todo el país, fundamentalmente en el marco del conflicto bélico.

No es la intención de esta investigación polemizar sobre este punto, sino dejar sentada la verdadera dimensión de las cosas para que nadie confundido, quizás, por señales equivocadas, o mal intencionado- vuelva a repetir la tragedia. Baste por el momento afirmar que, en el caso salvadoreño, no se puede hablar de sucesos aislados, imputables única y exclusivamente a los subalternos del grado más inferior. La distribución en el espacio y el tiempo de las violaciones a los derechos humanos y las modalidades de su realización -que muchas instituciones nacionales e intemacionales autorizadas han documentado y analizado - señala más allá de simples actuaciones desviadas y erráticas de algunos militares; apunta en realidad a un plan concertado y a conductas reiteradas.

Si se hubiesen documentado unos pocos casos aislados de ejecuciones extrajudiciales, desapariciones forzadas, torturas, detenciones arbitrarias e infracciones al derecho intemacional humanitario sería impensable hablar de prácticas sistemáticas y de órdenes superiores para ejecutar tales hechos. Sin embargo, las modalidades similares y la magnitud de las violaciones así como su ejecución en todo lo ancho y largo del país, señalan más bien lo contrario: la existencia de verdaderas y graves prácticas sistemáticas de violación a los derechos humanos; la realización de sendos crímenes de guerra y de lesa humanidad.

La jurisprudencia internacional señala que existe una práctica de violación a los derechos humanos cuando concurren los siguientes elementos: una pluralidad de infracciones de la misma naturaleza y la tolerancia de éstas por parte de las autoridades superiores del Estado. ${ }^{10} \mathrm{Y}$ eso sucedió en El Salvador.

10. Véase el estudio sobre las leyes de amnistía y el papel que desempeñan en la salvaguardia y la promoción de los derechos humanos: informe de Louis Joinet, relator especial de la Subcomisión de Prevención de Discriminaciones y Protección a las Minorías de las Naciones Unidas, documento E/CN.4/Sub.2/1985/16/Rev.1, párrafo 66 y siguientes. 
Los casos que diversas organizaciones e instituciones civiles de derechos humanos han denunciado constantemente, poseen características en extremo similares como para pensar que forman parte de una campaña política propagandística de desprestigio a la institución armada y al gobierno. Un estudio somero de los mismos evidencia demasiadas coincidencias como para decir que no son ciertos; por el contrario, muestran una realidad escalofriante y pasmosa. Sin contar con los recursos y la capacidad de los organismos estatales para llegar al último peldaño de la verdad en cada caso, dichas entidades lograron establecer en muchas ocasiones - suficientes, más bien- la responsabilidad de la Fuerza Armada.

Podrá decirse - como ya se ha hecho- que las denuncias responden a intereses políticos $\mathrm{y}$, por tanto, son inexactas o totalmente falsas. Pero nadie de la Fiscalía General de la República, el Órgano Judicial y la institución castrense hizo algo serio para averiguar la verdad y de ahí poder desvirtuarlas; siempre se recurrió a la calumnia y al desprestigio, cuando no a la persecución directa de quienes se atrevieron a investigar y difundir los hechos. Atacaron y atacan intentando desprestigiar la fuente, sin detenerse siquiera a corroborar si hay algo de verdad en lo que se decía y se dice.

En todo caso, la intención de quien revela estas atrocidades no es dañar a la Fuerza Armada como institución, sino señalar a los responsables de su conducción errónea y de su involucramiento ilícito como parte del Estado en graves hechos de violencia. Los que desprestigiaron a la FAES fueron aquellos que -dentro o fuera de ella- permitieron, fomentaron, organizaron u ordenaron la violencia oficial desproporcionada para atacar a la oposición armada y a todas aquellas personas que, desde la óptica militar, subvertían la institucionalidad establecida sin importar que fuesen religiosas, sindicalistas, políticas, docentes, niñas, niños, hombres, mujeres o adultos mayores.

Se debe recordar que, en muchas ocasiones, los militares actuaron pública e injustificadamente contra la población civil. Claros ejemplos de ello son la famosa lista de "enemigos de la patria" dada a conocer por el alto mando a principios de la década pasada o los constantes ataques contra la
Compañía de Jesús, así como los cateos y las campañas difamatorias contra organizaciones de derechos humanos y muchos otros sucesos. En la etapa actual, cuando se abre como posibilidad la construcción de un Estado democrático y participativo de Derecho, es tiempo de sentar las bases para que nada de eso se repita.

Los casos que denunciaron las organizaciones e instituciones civiles en muy pocas ocasiones señalan la responsabilidad individual de quién dio la orden para ejecutar determinada violación a los derechos humanos. No podrían hacerlo por una serie de factores: el modus operandi, pues quienes ejecutaban las acciones eran subalternos o se intentaba ocultar la identidad de los autores; la escasa o nula posibilidad de acceder a otras pruebas que no fueran declaraciones de víctimas o testigos del hecho; y la poca colaboración de las autoridades estatales. En esas condiciones, a lo más que podían aspirar era a identificar la unidad militar que consumó el hecho. Así, en muy pocos casos presentados se encontrará una relación directa de responsabilidad individual de oficiales.

Pero es necesario establecer esa responsabilidad, como se ha hecho en otros lugares de Latinoamérica y hasta en la vecina República de Honduras. $Y$ se puede, al hacer la relación del acto denunciado donde se señala a una unidad militar concreta con el oficial a cargo de la unidad y su ejecutivo en la época del suceso; aunque podría lograrse más si se tuviese acceso a los libros de operaciones o a la información de las secciones de inteligencia militar, en los que se señala quién estuvo a cargo de operaciones militares específicas, ${ }^{11}$ si es que todo eso no ha sido destruido o tergiversado. Pero ni siquiera la Comisión de la Verdad pudo acceder a esos datos, por la vía de una colaboración institucional real y plena.

La dificultad de allegar pruebas directas no descarga de responsabilidad a los oficiales al mando. En materia de derechos humanos, se ha aceptado internacionalmente que basta la prueba indiciaria o presuntiva para llegar a conclusiones firmes respecto de una violación a los mismos, sin las formalidades y el señalamiento concreto de responsabilidad a individuos que exige el derecho penal. $^{12}$

11. Los militares tienen la obligación legal de llevar un registro pormenorizado de sus acciones, según los artículos 397 y 398 de la Ordenanza del Ejército.

12. Corte Interamericana de Derechos Humanos, caso "Velásquez Rodríguez", sentencia de 29 de julio de 1988, párrafos 122 a 139. 
¿Cuál es, pues, la responsabilidad de los oficiales respecto de los abusos, excesos, violaciones a los derechos humanos o como quiera llamárseles, cometidos por sus subalternos? Las experiencias de otros países pueden iluminar mucho en este sentido. Los tribunales de Nuremberg y Tokio; el juicio a los integrantes de las juntas militares en Argentina; los cargos contra el mandatario de la desaparecida Alemania oriental, Erick Honecker, por el asesinato de quienes intentaron atravesar el muro de Berlín, son sólo algunas de ellas. En todas esas situaciones, se ha aceptado que la responsabilidad apunta a los que diseñaron las políticas que ejecutaron sus subaltemos, incluso aunque no hayan habido órdenes directas respecto de cada víctima en particular.

A continuación se ofrecen algunos alegatos de descargo en relación a la responsabilidad de los mandos en actos de violación a los derechos humanos cometidas por elementos de la Fuerza Armada; pero también se demuestra la falsedad de los mismos.

Un argumento que se utiliza para eximirse de culpa por acciones ilegales realizadas por subalternos, es que éstos actuaron en franca desobediencia a las órdenes superiores o directrices normales de la Fuerza Armada. Si hubiesen sido unos pocos casos ese justificativo podría aceptarse, siempre que se tuviese la certesa de que se aplicaron sanciones severas a los hechores y que se adoptaron medidas eficaces para evitar desmanes similares en el futuro. Se sabe que esto útlimo no fue la generalidad, sino más bien -siendo demasiado benevolentes-alguna muy rara excepción.

No es posible afirmar que en todos los casos de violaciones a los derechos humanos realizadas por la
Fuerza Armada en El Salvador, pues, los hechores actuaron siempre por iniciativa propia. Y si así fuera, entonces los oficiales a cargo de estos efectivos fallaron en su deber de controlar, de guiar correctamente a sus tropas y de garantizar la legalidad de sus acciones, lo que - además de ser una falta grave del servicio, sumado a la reiteración de las conductas violatorias y a la constante inactividad para prevenir tales conductas en el futuro- es claro indicador de una permisividad cómplice.

También pueden intentar evadir la responsabilidad, alegando que no era posible controlar a todos los subaltemos o que dependían de sus informes para la apreciación de los actos. Estas afirmaciones dejan al descubierto o una negligencia tremenda o un intento por encubrir y tergiversar los hechos; en ambos supuestos, la responsabilidad es grave.

El caso de la masacre de diez campesinos en San Sebastián, departamento de San Vicente, el 21 de septiembre de 1988 es típico. Cuando se cuestionó sobre esta matanza al general Adolfo Onecífero Blandón, en ese entonces jefe del Estado Mayor Conjunto de la Fuerza Armada, sobre la veracidad de las declaraciones vertidas por el Comité de Prensa de la Fuerza Armada (COPREFA) ${ }^{13}$ frente al testimonio de los habitantes de la zona, éste responsabilizó al jefe del Destacamento Número 5, coronel Mauricio Chávez Cáceres, por las informaciones inexactas que - sobre los sucesos- le había brindado. Aun así, nada se hizo contra el responsable de esas declaraciones tergiversadas. De todas formas, no desmintió las versiones falsas del COPREFA alrededor de los hechos ni sancionó a su encargado.

Lo anterior demuestra un desprecio claro hacia la verdad, las autoridades civiles y la sociedad

13. En un primer momento, el Departamento de Relaciones Públicas de la FAES informó que habian muerto “diez terroristas" que chocaron con tropas del Batallón Jiboa, adscrito a la 5" Brigada de Infantería, cuando "los extremistas deambulaban por la zona sin aparente destino fijo". Además, dijeron que -en el sitio del "combate"- los soldados recogieron armas de guerra, explosivos y equipo militar (La Prensa Gráfica, 25 de septiembre de 1988). Al día siguiente, el COPREFA inform6: "Que de acuerdo a versiones de la 5 ' Brigada de Infantería, efectivos militares del Batallón Jiboa procedieron a la detención de ocho personas en vías de investigación, por tenerse conocimiento previo de su participación con las organizaciones clandestinas del FMLN... Que cuando las tropas de dicho Batallón, juntamente con los detenidos transitaban a la altura del lugar conocido como La Cebadilla, en aquella población (San Sebastián) fueron atacados sorpresivamente con explosivos y fuego de fusilería por parte de grupos terroristas, habiendo provocado la muerte de los capturados y dejando a un soldado herido... Que de los atacantes, dos de ellos también murieron al ser repelidos por las unidades militares (La Prensa Gráfica, 26 de septiembre de 1988). El general Blandón, por su parte, declaró que "no se supo a ciencia cierta si los terroristas querían liberar a sus ex compañeros o asesinarlos para ocultar crímenes o impedir que dieran información que pudiera resultar valiosa para el Ejército" (La Prensa Gráfica, 24 de septiembre de 1988). 
misma. Sólo cuando se recibieron presiones extremas desde el ámbito internacional o cuando la prensa, nacional y extranjera, imposibilitó que se siguiera cubriendo la brutalidad se lograron algunos resultados en ésta y otras violaciones a los derechos humanos, aunque no los más óptimos.

En el juicio contra las juntas militares en Argentina, el fiscal Julio César Strassera manifestó que "no podía concebirse que en un ejército existiera un grado de insubordinación tal que permitiera que oficiales inferiores realizaran, durante varios años y en todas las provincias, acciones contrarias a las que ordenaba su comandante. Era por eso que, ... con la referencia a supuestos excesos, los comandantes trataban en realidad de eludir su responsabilidad atribuyéndosela a sus subordinados". ${ }^{14}$ Este razonamiento puede aplicarse, sin más, al caso salvadoreño.

Desde el punto de vista de la normativa militar, la Ordenanza del Ejército contiene diversas disposiciones que claramente señalan responsabilidad de los superiores por una real o supuesta negligencia en la vigilancia de los actos de los subordinados. Según ese cuerpo de leyes, «el militar no debe eludir responsabilidad ... Será también responsable el superior de las faltas, abusos y desordenes que resultaren de su negligencia o debilidad ante la conducta de sus subaltemos" (Art.9, incisos 2 y 3). Además, se establece que: "Ningún oficial se podrá disculpar por la omisión o descuido de sus inferiores en los asuntos que pueda y deba vigilar por sí mismo; en ese concepto, todo superior hará cargo de las faltas que notare al inmediato subalterno, quien debe ejecutar y hacer cumplir sus órdenes; y si éste resultare culpable, tomará la providencia correspondiente, en inteligencia de que por el disimulo recaerá sobre el superior la responsabilidad" (Art. 373).

De igual forma, señala que: "En cualquier oficial que mande a otros o se halle solo a la cabeza de una tropa, será prueba de corto espíritu e ineptitud en el mando el decir que no alcanzó a contener a la tropa a su orden; que él solo no pudo sujetar a tantos, y otras expresiones dirigidas con el fin de disculparse de los excesos de su gente o de su cobardía en las acciones de guerra; pues el que manda, desde que se pone a la cabeza de su tropa, ha de celar la obediencia en todo e inspirar el valor y el desprecio de los riesgos" (Art. 375).

Alegar ignorancia alrededor de los desmanes cometidos por la tropa tampoco es aceptable bajo ningún punto de vista. Dada la reiteración de conductas ilegales y su magnitud - como las constantes detenciones e interrogatorios efectuados por elementos de la FAES, en contravención a los requisitos exigidos por el Código Procesal Penal, así como las torturas y los operativos indiscriminados contra la población civil- resulta imposible que, sobre los hechos, haya podido existir un desconocimiento por parte de la superioridad a cargo de las unidades militares involucradas en los mismos. Las constantes denuncias de las organizaciones civiles y de la comunidad internacional, además, garantizaban que los oficiales supieran o iniciaran alguna investigación sobre lo que estaba sucediendo.

Lo absurdo de la hipótesis sobre los excesos de la tropa o de lo imposible que resultaba conocer absolutamente todos los hechos, nos llevan a afirmar que existe - por encima de la incapacidad militar - una clara responsabilidad penal de los oficiales al mando. Existían múltiples evidencias de que se estaban perpetrando delitos atroces, 10 que debió obligar a la oficialidad a evitarlos y a hacerlos del conocimiento de las autoridades competentes. Al no proceder así, su conducta podría enmarcarse en alguno o algunos de los siguientes tipos penales: Omisión Punible (Art.472, C.Pn.), Otras Omisiones Punibles (Art.474, inciso 2, C.Pn.) u Omisión de Aviso (Art.476, C.Pn.), cuando no en delitos más graves como el Encubrimiento Personal (Art.470, C.Pn.) o el Encubrimiento Real (Art.471, C.Pn.), al ayudar directamente a que los autores eludiesen la acción de la justicia. En el Código de Justicia Militar también existen figuras como la del el artículo 80 , según el cual un oficial que no ponga todos los medios que estén a su alcance para evitar que sus subalternos cometan actos de devastación, saqueo o pillaje recibirá pena de reclusión de cinco a diez años.

Como se observa, la omisión de actuar o denunciar es un hecho delictivo en sí; pero, además, respecto de la violación concreta también existe responsabilidad directa. En el derecho internacional se ha aceptado que la omisión opuesta al deber

14. Citado en Amnistía Internacional: “Argentina, Los Militares ante la Justicia”. Publicaciones de Amnistía Internacional, Madrid, 1987, p.27. 
de actuar de los oficiales superiores, puede acarrearles culpabilidad de infracciones cometidas por sus subordinados ${ }^{15}$ y que el hecho de que una infracción haya sido cometida por un subordinado no exime a sus superiores de responsabilidad, si éstos sabían que podía cometerse tal infracción y si no tomaron medidas para impedirla o reprimirla. ${ }^{16}$

En el derecho penal interno, la figura de la Comisión por Omisión también señala responsabilidad en este tipo de situaciones. Según el artículo 22 del Código Penal, "el que omite impedir un resultado que de acuerdo con las circunstancias podía y debía evitar, responde como si lo hubiera producido"; también dice que "el deber de obrar incumbe a quien tenga por ley obligaciones de cuidado, protección o vigilancia; o a quien con su comportamiento precedente creó el riesgo..." Los jefes militares, obviamente, podían y debían evitar las violaciones a los derechos humanos cometidas por sus tropas y tenían, por ley, la obligación de vigilar a sus subordinados.

Mirando más allá, se podría preguntar si no fueron los mismos oficiales quienes - con sus conductas precedentes - crearon una verdadera situación de riesgo o peligro para la población y para muchas organizaciones civiles, al señalarlas indiscriminadamente como "fachadas", "masas" o simpatizantes del FMLN, estigmatizándolos en consecuencia como "enemigos" de la Fuerza Armada y exponiéndolos a cualquier tipo de abusos y atropellos por parte de sus miembros - lo que de hecho sucedió - sin que hiciesen nada para detenerlos. En este supuesto, también hay responsabilidad legal y, sobre todo, ética y moral. La matanza en la UCA es, por demás, reveladora de esta forma de comisión de un hecho punible.

Sólo las distintas facetas de las conductas omisivas, como se ha señalado, entrañan una grave responsabilidad para los oficiales al mando de las tropas. Sin embargo, existe una serie de circunstancias que comprueban, más bien, la existencia de un plan concertado para realizar acciones violatorias a los derechos humanos como parte de la estrategia política y bélica; como consecuencia lógica de lo anterior, se deriva la existencia de órdenes superiores para llevar a cabo dicho plan. Estos dos últimos ingredientes -acción concertada y órdenes superiores - significan evidentemente un grado mayor de responsabilidad para los mandos militares.

Los siguientes son algunos elementos que demuestran lo imposible que resulta siquiera imaginar que las violaciones a los derechos humanos, cometidas por elementos de la Fuerza Armada, hayan sido desviaciones y actos aislados:

(a) Ya se ha dicho antes que la distribución espacio-temporal y la magnitud de las violaciones fue tal, que hace impensable un nivel tan grande de permisividad, desobediencia e insubordinación en cualquier institución castrense. Más bien, significa la presencia de una concepción centralizada en los mandos para cometer las violaciones a los derechos humanos y una ejecución descentralizada en todas las zonas militares.

(b) Si las violaciones a los derechos humanos hubiesen sido cometidas por oficiales o elementos de la Fuerza Armada desobedientes a las normas generales de conducta, no hubiese habido necesidad de ocultar la verdad o tergiversar los hechos ante la opinión pública y los organismos internacionales especializados de las Naciones Unidas y del sistema interamericano, ni tampoco de desnaturalizar el aparato estatal de justicia para encubrirlos. Es en extremo «sospechoso» que pocos miembros de la FAES hayan sido remitidos a los tribunales para enfrentar cargos criminales, pese a la magnitud preocupante de las violaciones a los derechos humanos constatados por instancias de la más diversa índole, incluido el Congreso estadounidense y el Departamento de Estado de ese país.

(c) Las modalidades utilizadas para cometer las violaciones fueron demasiado similares como para no pensar en patrones establecidos. Esa reiteración de conductas ilegales, registraòa en los testimonios y pruebas que la Comisión de la Verdad tuvo en sus manos, sería casi inconcebible si no hubiese existido una voluntad superior que planificó, dirigió y ordenó su ejecución. En el mismo sentido, la constante impunidad de sus autores necesitaba un centro de poder que la garantizara.

(d) Dada la estructura de cualquier institución armada del mundo, un subalterno no puede actuar sin órdenes superiores. La naturaleza de un ejérci-

15. Párrafo 1 del artículo 86, Protocolo I Adicional de 1977 a los Convenios de Ginebra de 1949. 16. Párrafo 2 del artículo 86, Protocolo I Adicional de 1977 a los Convenios de Ginebra de 1949. 
to es esencialmente jerárquica y descansa radicalmente en la obediencia a los mandos, especialmente en una situación de guerra. ${ }^{17} \mathrm{~A}$ lo largo del conflicto, los responsables de la conducción de la FAES constantemente manifestaban que no existían grupos en su interior que actuaran por cuenta propia; más bien, presumían de tener el control efectivo y total del accionar de sus tropas. Esa sola afirmación dejaría probada la existencia de órdenes superiores para cometer abusos contra los derechos humanos, como parte de la estrategia de guerra, pues las tropas habrían sido estrictamente obedientes a los designios de sus oficiales y jamás habrían actuado con independencia del mando.

(e) En lo que respecta a la práctica sistemática de detenciones ilegales o arbitrarias, incluso hubo órdenes escritas para la realización de actos contrarios a los más elementales derechos humanos como las garantías del debido proceso. Diversos "Procedimientos Operativos Normales" (PON) emitidos por el alto mando de la Fuerza Armada, señalaban las formalidades a seguir al realizar detenciones; dichas "normas" reconocían la facultad de la FAES para capturar supuestos o reales imputados en delitos políticos, interrogarlos y mantenerlos detenidos, en franca contravención a las disposiciones legales; ${ }^{18}$ e incluso regulaban la incomunicación de los detenidos.

(f) En no pocas oportunidades, altas autoridades castrenses reivindicaron y defendieron públicamente conductas reñidas con los derechos humanos y con el derecho internacional humanitario. Ello indica que, en consecuencia, los oficiales ordenaron efectivamente la ejecución de las mismas a sus subalternos. ${ }^{19}$
Una vez presentadas las razones con las cuales se establece que existieron violaciones y abusos contra los derechos y libertades fundamentales así como infracciones contra el derecho internacional humanitario, ordenadas como parte de un plan general concertado, se debe pasar a hacer algunas precisiones sobre la responsabilidad que le compete a los oficiales de la Fuerza Armada en los hechos violatorios cometidos por sus efectivos.

En principio, para tener un grado de responsabilidad no es necesario que las órdenes del servicio militar sean reiteradas constantemente ni que los oficiales superiores estén presentes en la zona donde se ejecutan tales hechos; basta diseñar un plan general o un patrón de conducta. Esta afirmación es válida tanto para las violaciones a los derechos humanos como para las infracciones al derecho internacional humanitario; por ello, no es necesario comprobar en cada caso la existencia de ordenes concretas y específicas ni la presencia física de los oficiales en el lugar.

En el mismo sentido, tampoco es necesario saber exactamente quién era el oficial al mando de cada operativo que resultó en una violación a los derechos humanos; bastaría saber en qué jurisdicción ocurrieron los hechos y si estuvo involucrado personal militar, para encontrar la responsabilidad del comandante de la zona y su ejecutivo. Se afirma esto, tomando en cuenta la estructura de la FAES.

La Ordenanza del Ejército señala que la división político administrativa en departamentos, servirá de base para las guarniciones en que se dividirá la tropa permanente y que cada guamición deberá considerarse como dependiente del mando

17. No podrían efectuarse constantes detenciones y torturas en las instalaciones militares, bombardeos aéreos y operativos que destruyesen vidas y bienes civiles, sin la decisión de los oficiales al mando. Estas prácticas en especial demuestran la existencia de órdenes superiores.

18. Según el Código Procesal Penal, la Fuerza Armada sólo tiene facultad para capturar a un imputado en flagrancia al igual que lo podría hacer cualquier otro ciudadano común, para el único efecto de remitirlo inmediatamente a las autoridades competentes, sin posibilidades de mantenerlo detenido en sus instalaciones.

19. Por ejemplo, el coronel Jorge Alberto Cruz Reyes, cuando era comandante del Destacamento Militar No 4, justificó los ataques contra la población civil ante los periodistas diciendo que cuando el FMLN estaba presente, los civiles "que no quieren cooperar abandonan el área mientras que los que permanecen son colaboradores" (Mary Jo McConahay, "Little know air war terrorizes population in rural El Salvador", National Catholic Reporter, 20 de abril de 1984). El coronel Sigifredo Ochoa, por su parte, dijo ante un periodista que podía bombardear masivamente las zonas rojas porque sólo subversivos viven en ellas (Carlos Ramos, "Puedo bombardear zonas donde hay subversivos", La Jornada, México, 19 de enero de 1985). Ambos oficiales fueron citados en el artículo "Combatiendo la guerrilla: Estados Unidos y la Estrategia de Conflictos de Baja Intensidad en El Salvador" de Tommie Sue Montgomery y Agnes Scott College, Revista ECA, abril de 1991, p. 278. De la misma manera, fue justificado por el alto mando militar el bombardeo aéreo en zonas densamente pobladas durante la ofensiva insurgente de 1989. 
supremo de la institución. Así, siempre existe el mando de un comandante y donde juzgue conveniente la Comandancia General de la FAES se establecerán guamiciones subalternas, denominados destacamentos, que dependerán de la respectiva comandancia superior. ${ }^{20}$ De esta manera, el comandante de la región o zona es el responsable de todas las acciones militares que se efectúen en su jurisdicción, incluso aquéllas efectuadas por unidades móviles del ejército que no estaban adscritas a un mando territorial, como las realizadas por cualquier Batallón de Infantería de Reacción Inmediata de los que existieron durante la guerra. ${ }^{21}$

Esa división territorial debería facilitar la búsqueda de responsabilidades penales y militares en los mandos por violaciones a los derechos humanos y a las normas de la guerra, según la jurisdicción en que se hayan producido. También es posible examinar la responsabilidad legal de los integrantes del Estado Mayor Conjunto de la Fuerza Armada, por ser la principal autoridad militar del país desde donde se diseñó el plan contrainsurgente y desde donde se debía controlar la ejecución del mismo.

Sin duda, se pueden ubicar dos niveles de responsabilidad: la de los oficiales inferiores, que ejecutaron las órdenes o aplicaron políticas de acción, y la de los oficiales superiores, que dictaron las órdenes o diseñaron las políticas. Respecto de los oficiales inferiores, la responsabilidad penal en el cumplimiento de órdenes ilegales o prácticas violatorias a los derechos humanos es clara. En estos casos no pueden alegar la eximente de obe- diencia debida, lo que está suficientemente aceptado en el derecho internacional y se encuentra reconocido por la legislación nacional. ${ }^{22} \mathrm{El}$ Código Penal salvadoreño, según su artículo 40 , acepta la obediencia debida como causa de inculpabilidad siempre que:

- La orden emane de autoridad competente para expedirla y reúna las formalidades legales.

- El agente esté jerárquicamente subordinado a quien expida la orden.

- Lo ordenado no revista manifiestamente el carácter de hecho punible.

Ese último requisito es el que impide considerar a los oficiales inferiores que se convirtieron en ejecutores materiales como inculpables, por cuanto las violaciones a los derechos humanos $y$ al derecho internacional humanitario revisten una manifiesta ilicitud.

Por otra parte, cuando un oficial superior diseña políticas o dicta órdenes violatorias a los derechos humanos a un oficial subordinado y éste a su vez —en cumplimiento de las mismas - ordena la ejecución material a sus subalternos, se convierte en jefe y en consecuencia asume la responsabilidad que les compete a los que actúan directamente. En otras palabras, el oficial inferior es culpable si -en cumplimiento de órdenes superioresimparte órdenes que derivan en violación a los derechos humanos; peor aún: si las órdenes superiores no son ilegales y el oficial subordinado comete un hecho ilícito al cumplirlas, es evidente que toda la responsabilidad recae sobre él. ${ }^{23}$

20. Estas disposiciones se encuentran en los artículos 175 a 177 de la Ordenanza.

21. Durante el conflicto, estas unidades debían reportarse con el respectivo comandante de la región antes de operar en la zona.

22. "El subordinado que comete un delito según el derecho internacional debe ser declarado culpable y condenado... La idea de que las órdenes superiores no constituyen excusa penal está incorporada en el derecho consuetudinario zonal entre los estados occidentales y socialistas... Actualmente, gran número de países reconoce en su derecho interno que la excusa de las órdenes superiores no exime de responsabilidad penal al subordinado. Esta disposición figura, según la tradición jurídica de los países concernidos, sea en el código penal militar sea en el código penal o, a veces, forma parte de la jurisprudencia. En todo caso, la solución a la que se llega dimana de los principios enunciados en los juicios de Nuremberg y de Tokio... " Maurice Aubert, "La cuestión de las órdenes superiores y la responsabilidad de los jefes en el Protocolo adicional a los Convenios de Ginebra del 12 de agosto de 1949, relativo a la protección de las víctimas de los conflictos armados internacionales (Protocolo I) del 8 de junio de 1977", Revista Internacional de la Cruz Roja, marzo-abril de 1988, pp. 110, 114.

23. "Hay que distinguir, como hizo el Tribunal de Nuremberg, entre la orden "indeterminada" que deja al subordinado dar la orden de ejecución de la cual será responsable (ejemplo: el regimiento de carros blindados tiene orden de avanzar en tal dirección) y la orden "estricta" que no deja margen de apreciación a quien debe ejecutarla (ejemplo: todo prisionero de guerra evadido que sea recapturado será inmediatamente ejecutado). En el primer 
En lo que respecta a los oficiales superiores, hay que preguntarse si pueden ser considerados autores de los hechos delictivos cometidos por la tropa, si no participan directamente en su ejecución material y si únicamente estaban al mando de la Fuerza Armada. La respuesta a todo ello es afirmativa, al utilizar las nociones de aparato organizado de poder, dominio del hecho y autor mediato.

El fiscal en el juicio contra las juntas militares en Argentina, Julio César Strassera, señaló que "la expresión "aparato organizado de poder" es admitida hoy sin discrepancias en la doctrina penal y que se trata de un tipo de organización con un centro de decisión desde el cual se imparten las directivas. Es en este centro de decisiones donde está la posibilidad de cometer o no cometer los delitos de que se trataba. El centro de decisión domina el hecho de modo tal que, tomada la decisión de que ocurra determinado delito, éste acontece automáticamente. El encargo se cumple sin necesidad de que el centro de decisión conozca al ejecutor concreto; esto es la fungibilidad de los ejecutores. En el supuesto de que alguno de ellos no cumpliera la decisión tomada, otro se encargaría de hacerlo en su lugar, puesto que la estructura posee la capacidad de reemplazo necesaria para que cada parte de la máquina sea sustituida por otra de manera que la orden se cumpla al final inexorablemente". ${ }^{24}$

Así, la voluntad de quien maneja el aparato organizado de poder está detrás de la ejecución de los hechos y los determina. Una vez dictada una orden o decretadas las directivas del delito, su realización es casi automática, y la identidad o individualidad del autor inmediato se vuelve secundaria. Si ese aparato organizado de poder se encuentra ubicado en el mando superior de una institución castrense, la naturaleza jerárquica y obediente que caracteriza a la misma garantiza en mayor medida la realización y eficacia del resultado. Los superiores siempre habrian tenido el dominio sobre las actuaciones de sus subordinados.

Desde el punto de vista del derecho penal salvadoreño, la participación de los oficiales que dictaron las órdenes o diseñaron las políticas violatorias a los derechos humanos entra bajo la categoría de autores mediatos de las mismas. El artículo 46, numeral 3, C.Pn. concibe como autores mediatos los que dictan las 6́rdenes ilegales en el caso del artículo 40 C.Pn., arriba citado. ${ }^{25}$

"La distinción entre autores mediatos o inmediatos - se dice en la exposición de motivos del proyecto de Código Penal salvadoreño de 1973alude únicamente a la menor o mayor proximidad de la conducta del delincuente a los actos materiales en que se objetiviza la ejecución del delito; en manera alguna significa que la responsabilidad penal de los primeros deba ser necesariamente menor que la de los segundos. El autor mediato no interviene directamente en el período de consumación del delito, sino que lo ha planeado con anterioridad y, mediante concierto, precio, promesa de recompensa, amenaza o cualquier otro medio, logra que lo ejecute un autor inmediato... son muy variadas las formas que puede asumir este tipo de delincuentes y ... (el autor mediato) es fácilmente reconocible por tener a su cargo la dirección intelectual de las operaciones delictuosas... (Una) categoría de autores mediatos es la de los que valiéndose de su alta jerarquía de funcionarios, emite, con las formalidades legales, órdenes que entrañan la comisión de delitos".

$\mathrm{Y}$ agrega lo siguiente: "El subalterno que, en este caso, obedece por error la orden delictuosa, es irresponsable por inculpabilidad, pero no lo es el autor mediato. La responsabilidad penal del funcionario no desaparece por el hecho de que en otra hipótesis, el autor inmediato obedezca la orden a sabiendas de que es ilegal y también él incuma en responsabilidad al cumplirla; en este último

caso, el jefe del regimiento puede y debe tener en cuenta, cuando formule su orden, las normas del derecho internacional humanitario. En el segundo, aunque en el derecho nacional bajo cuya jurisdicción está el jefe del campamento de prisioneros no figuren los principios de Nuremberg, es su deber no cumplir una orden que, a su juicio, es inadmisible puesto que, transmitiéndola a sus subordinados, comprometería su responsabilidad. Una orden tachada de ilicitud no debe ser ejecutada; el jefe que la reciba tiene el deber de rechazarla, a reserva de poder aducir, como prueba liberatoria, la presión a la que se viera sometido". Maurice Aubert, ibld, p. 119.

24. Citado en Amnistía Internacional, op.cit., p.38.

25. En el mismo espíritu, el artículo 9, inciso, 2 de la Ordenanza del Ejército, señala que corresponde al superior la responsabilidad de todas las órdenes que dictare.

26. Exposición de motivos y proyecto del Código Penal salvadoreño, 1973, mimeo. 
caso el que dio la orden antijurídica está incluido en el concepto general de autor mediato". La noción del autor mediato, en este caso, responde a la teoría del dominio del hecho. El superior es culpable independientemente de la eventual responsabilidad del autor material o inmediato, el cual se vuelve una pieza sustituible en la maquinaria delictiva.

La misma doctrina militar reconoce la responsabilidad de los jefes como dirigentes o autores intelectuales en hechos delictivos cometidos por la tropa. Es el caso de la rebelión, por ejemplo. Al respecto, el artículo 80 del Código de Justicia Militar dice: "Si no pudiere descubrirse quiénes son los jefes, caudillos o promotores de la rebelión, se presumirá legalmente que lo son quienes tomen el mando superior de las fuerzas o elementos rebeldes, o lleven la voz por ellos, o firmen proclamas u otros escritos expedidos a su nombre o ejerzan otros actos semejantes en representación de los demás. Si de los que tomaron parte en la rebelión, ninguna persona está en los casos señalados en el inciso anterior, se presumirá legalmente que son jefes o cabecillas de la rebelión los militares de mayor graduación o antigüedad". Como se aprecia, los ilícitos de la tropa son considerados como ejecutados y determinados a través de una cadena jerarquizada de mando, en cuya punta superior recae la responsabilidad última de los hechos.

Existe otra visión que explica la naturaleza de la intervención de los jefes militares, alternativa a la teoría del autor mediato. Dicha visión está resumida en la sentencia de la Corte Suprema de Justicia Argentina cuando conoció de los recursos extraordinarios presentados en el juicio contra los integrantes de las juntas militares. En ella, dicho tribunal no consideró como autores mediatos a los altos jefes militares sino como partícipes necesarios en los delitos cometidos por las tropas, mediante el siguiente razonamiento: "Cabe concluir en que, al emitir los procesados las órdenes verbales secretas e ilegales para combatir el fenómeno terrorista, como así también al proporcionar a sus ejecutores directos los medios necesarios para cumplirlas, asegurándoles que luego de cometidos los delitos no serían perseguidos ni deberían responder por ellos, garantizando su impunidad, han realizado una cooperación necesaria consistente en la contribución acordada con otros partícipes para la comisión del hecho".

Si hemos establecido que altos oficiales del ejército estuvieron involucrados en graves hechos de violencia, todavía queda por contestar una interrogante: esas conductas, ¿estaban justificadas, dada la situación que debía enfrentar la FAES? La respuesta, sin duda, es una: no existe justificativo alguno para violar los derechos humanos o para cometer infracciones al derecho internacional humanitario en forma sistemática o eventualmente, a pesar de los ataques armados desde el extranjero o del interior por fuerzas insurgentes. $\mathrm{Ni}$ siquiera podrían presentarse excusas penales sobre los hechos delictivos pues no se cumplen los requisitos para alegar - cuando se ataca en forma indiscriminada a la población civil no combatiente, por ejemplo- legítima defensa, estado de necesidad, cumplimiento del deber o cualquier otra eximente contemplada en el Código Penal o en el de Justicia Militar.

Sin lugar a dudas, para finalizar esta parte, conviene traer a cuenta el texto del informe de la Comisión de la Verdad, concretamente en el numeral 4 de la sección $C$, del capítulo IV titulado "El patrón de conducta". En él se lee lo siguiente: "Además de las masacres reseñadas, la Comisión recibió testimonios directos de numerosas ejecuciones masivas ocurridas en el transcurso de los años 1980, 1981 y 1982, en las cuales elementos de la Fuerza Armada, en el curso de operaciones antiguerrilleras, ejecutaron a campesinos, hombres, mujeres y niños, que no habían opuesto ninguna resistencia, simplemente por considerarlos colaboradores de los guerrilleros".

Más adelante, en el mismo numeral del documento, se dice que la Comisión descarta "toda posibilidad de que se haya tratado de incidentes aislados o de exceso de los soldados o sus jefes inmediatos". Y concluye, afirmando de manera categórica que "todo comprueba que estas muertes se inscriben dentro de un patrón de conducta, de una estrategia deliberada de eliminar y aterrorizar...", cuyo diseño y aplicación no pueden atribuirse a los mandos medios e inferiores ni, mucho menos, a la tropa. "Es imposible - se afirma- que este patrón de conducta sea atribuible sólo a los mandos locales, y que haya sido desconocido de los mandos superiores".

Y dentro de las máximas autoridades de la institución armada durante los veinte años más dolorosos de la historia nacional, se comprende tanto a quienes fungieron como sus comandantes generales durante esos años - principalmente los señores Jaime Abdul Gutiérrez, José Napoleón Duarte y 
Alfredo Cristiani- así como a los oficiales que formaron parte del alto mando, aquellos que tuvieron a su cargo las distintas guarniciones militares y los que estuvieron al frente de las unidades élites de combate.

\section{Algunas posibles salidas}

En la introducción de este trabajo se mencionaron las dos comisiones discutidas y acordadas durante el proceso de negociación entre lạs partes beligerantes, cuyo objeto último - de una u otra forma - era el de coadyuvar a la superación real de la impunidad. Pero además de las anteriores instancias, cuya existencia era corta por definición propia, se diseñaron otros mecanismos temporales y permanentes en aras de reducir al mínimo la violencia y asegurar el castigo tanto para los criminales como para sus cómplices; así, parecía que por fin se había caído en la cuenta de que esa lacra la impunidad- era el gran obstáculo que impedía la construcción de un sólido Estado democrático y participativo de Derecho.

La labor investigativa del IDHUCA alrededor de esos veinte años - plagados de graves violaciones a los derechos humanos en el país- incluyó, además de la violencia y las negociaciones para ponerle fin, la etapa en la cual tuvieron vida la Misión de Observadores de las Naciones Unidas para El Salvador (ONUSAL), la Comisión de la Verdad, la Comisión ad hoc y el llamado "Grupo Conjunto" (para la investigación de los grupos armados ilegales con motivación política). Además, de 1992 a 1994, fue posible observar y reflexionar sobre el nacimiento y los primeros pasos de importantes instituciones creadas por los acuerdos de paz - Procuraduría para la Defensa de los Derechos Humanos (PDDH) y Policía Nacional Civil (PNC) - así como la puesta en marcha de las reformas al Órgano Judicial. Sobre algo de eso, también hay mucho de que hablar.

\subsection{El acuerdo de San José y la observación de la ONU}

El documento firmado en Costa Rica el 26 de julio de 1990, constituyó el primer acuerdo sustancial alcanzado por las partes beligerantes en el desarrollo de la negociación, pese a ser el segundo de los puntos de la agenda estratégica definida en
Caracas el 21 de mayo de ese mismo año. Este compromiso político fue recibido con esperanza dentro y fuera del país, al considerarlo un trascendental y positivo hito frente a la tenebrosa historia de abusos sistemáticos a los derechos humanos que padeció la mayor parte de la población salvadoreña durante mucho tiempo.

Como se dijo antes, para esta ronda negociadora no se tenía prevista la discusión sobre el tema de los derechos humanos. La reunión tenía por objeto tratar lo relativo a las Fuerzas Armadas; pero, por su misma naturaleza, este punto de agenda generó intensos debates que obligaron al representante especial del secretario general de la ONU doctor Álvaro de Soto- a echar mano de su experiencia diplomática para superar un previsible entrampamiento y lograr que surgiera el importante compromiso asumido por el gobiemo y las fuerzas insurgentes.

El documento constaba de diecinueve artículos. En los nueve primeros se establecieron medidas de carácter jurídico y político, mediante las cuales se buscaba asegurar el efectivo cumplimiento y respeto de los derechos y las libertades fundamentales para todas las personas, sobre todo en lo que respecta a las garantías judiciales y las normas del debido proceso, así como otros derechos civiles y políticos que el orden jurídico de El Salvador incluye dentro de sí.

Sobre lo anterior -en concordancia con lo señalado en el romano uno de este artículo- es importante resaltar que la principal responsabilidad en el respeto a estos derechos se atribuyó especialmente al Estado. Así, el acuerdo de San José era claro al sostener lo siguiente: "el ordenamiento jurídico de El Salvador consagra el reconocimiento de los derechos humanos y el deber del Estado de respetarlos y garantizarlos"; en tanto, el compromiso del FMLN estaba limitado a "respetar los atributos inherentes a la persona humana". ${ }^{27} \mathrm{De}$ esa manera, se dejó plasmada la intrínseca dimensión de obligatoriedad que al Estado le correspondería en adelante para garantizar la vigencia de los derechos y las libertades fundamentales, masivamente violados desde la institucionalidad.

El segundo apartado del acuerdo contenía los diez restantes puntos consensuados y en ellos se

27. Acuerdo de San José sobre Derechos Humanos, apartado I, “Respeto y Garantía de los Derechos Humanos”. 
establecían los mecanismos para la verificación internacional, centrándose fundamentalmente en la creación de una misión especial de observadores de las Naciones Unidas que habria de supervisar - in situ- la efectiva vigencia de los derechos humanos, no sólo en relación a lo específicamente incorporado dentro del documento sino de toda la normatividad nacional e intemacional ratificada por El Salvador sobre la materia.

La firma del acuerdo de San José debe interpretarse, pues, como la aceptación oficial de la ausencia en el país de una política estatal de respeto, garantía y protección tanto a las normas del derecho intemacional de los derechos humanos como aquellas relativas al derecho internacional humanitario; también debe entenderse como el reconocimiento insurgente de su responsabilidad en acciones contra la dignidad humana. Con ese importante documento se admitió implícitamente, además, el incumplimiento estatal de su papel de garante; finalmente, fue aceptada la gravedad de la situación y admitido el valor de las normas internacionales de protección a los derechos humanos.

Entre los cuatro objetivos explícitos del proceso de pacificación se determinó el de "garantizar el irrestricto respeto a los derechos humanos";28 sin duda, ello constituyó un acertado primer paso de las partes para ubicar uno de los mayores retos para arribar a buen puerto. El acuerdo de San José resultó ser —en la práctica- el banderazo de salida para ese recorrido en el marco de la tarea común que se impusieron tanto el gobiemo como el FMLN, quienes concedieron a la verificación de las Naciones Unidas la autoridad política y moral para hacerla efectiva.

Dicho documento planteó los aspectos prioritarios que se debían atender con urgencia en relación a los derechos a la vida, a la integridad física, a la seguridad, a la libertad personal y al debido proceso legal. También las metas: identificación y sanción de los responsables, así como la erradicación de los patrones vigentes de violación a la dignidad de las personas. Es cierto que se le habló, igualmente, sobre derechos tales como los que tienen que ver con las libertades de asociación y expresión, laborales y de libre tránsito. Sin em- bargo, pudo percibirse en el compromiso de San José que se privilegió la atención de las expresiones más "escandalosas", en el afán por transitar a una situación distinta a la existente durante el conflicto social, político y bélico. Con todo, fue un logro invaluable el haber delineado también el perfil del comportamiento institucional que se necesitaba para romper con la dramática experiencia de violencia e impunidad que se generalizó en el país.

El IDHUCA expresó, oportunamente, su esperanza y optimismo sobre la Misión de Observadores de las Naciones Unidas en El Salvador (ONUSAL), sosteniendo que este intento de verificación especial debía interpretarse como una "presencia constante" que poseía todo lo que le faltaba "a los órganos estatales y a los distintos mecanismos de la ONU para revertir las estructuras de terror y las violaciones masivas de los derechos humanos". 29 Además, el Instituto afirmó que teóricamente hablando tenía "todas las herramientas necesarias para aportar a la solución del núcleo de las violaciones más graves, sistemáticas y persistentes: la impunidad".

Luego de un esfuerzo conjunto para evaluar la gestión de la división de derechos humanos de la Misión, las organizaciones sociales de defensa y promoción de derechos humanos - las llamadas "ONGs"- llegaron a las siguientes conclusiones generales:

(a) En sus recomendaciones, la división de ONUSAL abordó más una problemática global que situaciones particulares y específicas; eso explica la manera cómo desarrolló su labor de verificación y dio seguimiento a los casos.

(b) Sus recomendaciones no tenían carácter obligatorio ni se presionó para que fueran respetadas y aplicadas; su único peso era el político, que no siempre fue aprovechado en la materia.

(c) Valoró poco el aporte brindado por las organizaciones e instituciones civiles de derechos humanos.

(d) Tendió más a actuar diplomáticamente, haciendo equilibrio político; así, limitó sus posibilidades de desarrollar una presión efectiva e incidir

28. Acuerdo de Ginebra, numeral I, 4 de abril de 1990.

29. IDHUCA. "El Acuerdo de San José sobre Derechos Humanos: La Misión de Verificación", Revista Estudios Centroamericanos, ECA, Año XLV, No 504, San Salvador, El Salvador, 1990, p. 867. 
realmente sobre el comportamiento de las autoridades gubernamentales.

(e) Cuando tuvo alguna efectividad, ésta se ubicó principalmente en el hecho de que - por ser una instancia internacional-su presencia favoreció la prevención y evitó en parte que se incrementaran las violaciones a los derechos humanos.

(f) No pudo, sin embargo, tener una incidencia real en la investigación del delito. La mayor debilidad de la división se observó en su incapacidad para obtener —del Órgano Judicial y sus instancias auxiliares - investigaciones de la calidad que exige toda denuncia de violación a los derechos humanos, tanto de los hechos en sí como de sus responsables.

Así, pues, con todas las ventajas que tuvo la división de derechos humanos ONUSAL para desempeñar su labor verificadora, ésta no logró resultados satisfactorios; pese a algunas transformaciones que se experimentaron, tras su disolución quedaron estructuras -estatales y de la sociedadresistiéndose al cambio y realizando peligrosas acciones en sentido contrario. Cabe señalar que de los anteriores juicios sobre la división se salvan las, quizás demasiado cortas, administraciones encabezadas por el francés Phillipe Texier y el estadounidense Reed Brody.

\subsection{Comisión de la Verdad, Comisión ad hoc y "Grupo Conjunto"}

Grave huella sobre la sociedad salvadoreña constituyen las más de 70,000 personas asesinadas por motivaciones políticas y cerca de $\mathbf{8 , 0 0 0}$ desaparecidas forzadamente así como las decenas de miles detenidas arbitrariamente, torturadas y tratadas en forma inhumana, desplazadas, exiliadas y repatriadas junto a muchas otras que aún padecen - por diversas razones y de distintas maneras - las consecuencias de un plan criminal de exterminio, encaminado a contener el avance y desarrollo de la participación social.

La terrible experiencia a que fue sometido el pueblo salvadoreño dejó una profunda impresión en la conciencia de todas y todos los que creen en la dignidad humana. En ese marco, no es posible entonces permitir que el "perdón y el olvido" absoluto sean los fundamentos de una nueva convivencia, armoniosa y pacífica. Mucho menos que la aspiración para el futuro democrático y seguro descanse en el "borrón y la nueva cuenta" de los crímenes.

En orden de posibilitar el más amplio conocimiento de las condiciones y procesos que determinaron la situación de violación sistemática y estructural de los derechos humanos y con miras a superar la impunidad, se concertó en la negociación entre las partes la creación de la Comisión de la Verdad, la cual tendría a su cargo "...la investigación de graves hechos de violencia ocurridos desde 1980, cuya huella sobre la sociedad reclama con mayor urgencia el conocimiento de la verdad."

Se acordó además, crear una Comisión ad hoc para evaluar a los oficiales de la Fuerza Armada - como base para su depuración- tomando en cuenta la trayectoria de cada uno, especialmente en lo que respecta a sus antecedentes sobre la observancia del orden jurídico con énfasis en el respeto a los derechos humanos de la población, tanto en sus acciones personales como en el rigor con que dispusieron la corrección o sanción de hechos irregulares, uso excesivo de la fuerza y otras violaciones a los derechos humanos que se hubieran producido bajo su mando, especialmente si se observaron violaciones u omisiones graves o sistemáticas. De igual manera, esta Comisión especial evaluaría la competencia o vocación profesional de los oficiales con respecto a su actitud para desenvolverse en la nueva realidad de paz y sobre su disponibilidad para impulsar la democratización del país, garantizar el irrestricto respeto a los derechos humanos y reunificar a la sociedad salvadoreña.

Al finalizar su labor, las recomendaciones de la Comisión de la Verdad -incluidas en su informe presentado el 15 de marzo de 1993 - se centraron fundamentalmente en propiciar la desconcentración de funciones de la Corte Suprema de Justicia, la cual había contribuido en forma clara en el pasado para condicionar a magistrados y jueces inferiores e incluso profesionales del Derecho, a fin de desnaturalizar la impartición de justicia. Otras propuestas apuntarían a profundizar la labor iniciada por el Consejo Nacional de la Judicatura en la depuración e imposición de sanciones a jueces y magistrados del Órgano Judicial. Asimismo, se recomendó la investigación de grupos armados ilegales con fines políticos - léase: "escuadrones de la muerte"- que aún existiesen.

La Comisión también tenía por mandato el hacer las recomendaciones necesarias relacionadas 
con la adopción de medidas en orden de lograr respeto de los derechos humanos, que suponian una nueva proposición de reformas constitucionales. Éstas se complementarían con otras reformas derivadas de las recomendaciones arriba mencionadas $y$, en consecuencia, abrirían la posibilidad de un trascendental avance jurídico-político en la consecución del respeto a los derechos humanos y la transformación del sistema judicial.

Los compromisos establecidos en el acuerdo de Chapultepec junto a las recomendaciones hechas por la Comisión de la Verdad constituyeron, por tanto, pasos inéditos y básiscos para impulsar el proceso de profundas reformas que comenzaba a operarse en el sistema de impartición de justicia y en la superación de la impunidad. Sin embargo, pese a que la ejecución de dichos compromisos y sendas recomendaciones -que eran de obligatorio cumplimiento para las partes- debía expandirse en la conciencia de la sociedad civil y política como un amplio logro de toda la Nación, la población no llegó a apropiarse de lo que, en definitiva, constituía la llave para abrir la puerta ancha por la que debía irrumpir pleno el respeto a los derechos humanos en el país. Sin duda, la responsabilidad de ello recae -independientemente del grado- en las partes.

Ya antes, en el caso de la Comisión ad hoc, se habían iniciado las resistencias. Así, desde el comandante general de la FAES -en ese entonces el presidente Cristiani- se lanzaron señales peligrosas para el proceso. La Comisión, formada por tres salvadoreños notables e instalada en mayo de 1992, debía analizar la trayectoria de más de 2,000 oficiales y Cristiani contaba con 60 días, después de recibido el informe de la misma, para darle cumplimiento a sus recomendaciones.

Al respecto, vale la pena citar al entonces secretario general de la ONU. "El 22 de septiembre -narra Boutros Boutros-Ghali- la Comisión ad hoc había remitido su informe confidencial al presidente Cristiani y a mí. Cuando las recomendaciones de la Comisión empezaron a conocerse extraoficialmente y se supo que varios oficiales superiores y más de 100 en total estaban en la lista de los que serían dados de baja o reubicados, cundió el desasosiego entre el estamento militar, que consideró que los cambios eran demasiado extensos. Se dijo que perturbaba particularmente a la Fuerza Armada que el FMLN no tuviera que someterse a un proceso análogo de rendición de cuentas. El FMLN, por su parte, había decidido vincular su propia desmovilización al avance del proceso de depuración". ${ }^{30}$

Y continúa Ghali con sus revelaciones: "Como aumentaban las tensiones (uno de los tres miembros de la Comisión ad hoc informó haber recibido una amenaza anónima de muerte) y había vencido el plazo inicial del 31 de octubre de 1992 para poner fin al conflicto armado, decidi enviar a San Salvador al secretario general adjunto Sr. Goulding y al subsecretario general Sr. De Soto. El 6 de noviembre, tras ocho días de consultas, se llegó a acuerdo sobre las etapas siguientes del proceso de paz. El presidente Cristiani convino en informarme para el 29 de noviembre acerca de las decisiones administrativas que hubiese tomado con respecto a la depuración de la Fuerza Armada y en terminar el proceso para el 1 de enero de 1993". ${ }^{31}$ Para el funcionario internacional, se había entrado en una "etapa especialmente delicada".

El 1 de diciembre de 1992, Cristiani informó a Ghali que había adoptado las decisiones administrativas necesarias para dar por cumplidas las recomendaciones de la Comisión ad hoc. Sin embargo, el 7 de enero del siguiente año, el secretario general de la ONU notificó al Consejo de Seguridad del organismo que el gobiemo salvadoreño no había acatado a cabalidad dichas recomendaciones. Finalmente, Ghali informó el 7 de julio de 1993 "que, más de ocho meses después del plazo

30. Las Naciones Unidas y El Salvador, 1990-1995. Serie de Libros Azules de las Naciones Unidas, Volumen IV, Departamento de Información Pública, Naciones Unidas, Nueva York, párrafo 89, p. 33.

31. Ibid., párrafo 90. 
original, el gobierno de El Salvador había adoptado las medidas necesarias para la depuración de la Fuerza Armada". 32

Sin embargo, consta que no se cumplieron a cabalidad todas las recomendaciones y que las relacionadas con el alto mando castrense -oficiales de la llamada "tandona" - sólo se lograron cuando sus miembros cumplieron el tiempo de servicio, retirándose así con todos los grandes privilegios del cargo e incluso siendo objeto de homenajes por la autoridades civiles. El 1 de julio de 1993, al momento de transferir el mando del Ministerio de la Defensa Nacional, Cristiani habló de la "misión patriótica" cumplida por la FAES y destacó su "entrega y gran espíritu de servicio durante el conflicto". Por su parte, el ministro saliente - general René Emilio Ponce, seriamente involucrado en la matanza de la UCA - afirmó en esa ocasión que "ante la agresión comunista, la Fuerza Armada planificó, organizó y ejecutó la campaña militar contrasubversiva más exitosa de la época contemporánea".

He aquí la muestra de la tan sonado "éxito". Argumentando la defensa de la soberanía nacional y del orden público, el Estado salvadoreño asumió la doctrina de la seguridad nacional y la de "guerra de baja intensidad" para aniquilar a sus adversarios. De esa forma, poblaciones enteras fueron borradas del mapa; sus habitantes asesinados y los sobrevivientes obligados a buscar refugio en países vecinos. $Y$ es que las operaciones militares concertadas con ayuda de los Estados Unidos "cerco y aniquilamiento", "tierra arrasada", "yunque y martillo", entre otras - dentro de la estrategia militar de quebrantar la base social de los insurgentes, fueron dirigidas en gran medida contra la población civil no combatiente. Tristes ejemplos son las matanzas de El Mozote, en el departamento de Morazán y la del río Sumpul, al norte del departamento de Chalatenango, en complicidad con el ejército hondureño. Pero para Ponce al finalizar su mandato- fue así como obligaron "a los apátridas a desistir de su lucha armada".

Con ese antecedente de incumplimiento o de un simple acatamiento formal, las recomendaciones de la Comisión de la Verdad tampoco fueron cumplidas a cabalidad, especialmente las del último grupo: el de las medidas tendientes a la reconciliación nacional. De esa forma no se reconoció públicamente la honorabilidad de las víctimas ni se erigió un monumento en su honor, con los nombres de aquellas que aparecían en el informe de la Comisión; tampoco se decretó un día feriado para recordarlas ni se organizó el "foro de la verdad y la reconciliación"; mucho menos se les compensó materialmente a las personas que fueron afectadas, directa o indirectamente, por la violencia.

Cuanta razón tenía el ya citado Pedro Nikken, quien -en su último informe como experto independiente de la Comisión de Derechos Humanos de la ONU para El Salvador, presentado en febrero de 1994 - aseguró "que hasta entonces las recomendaciones de la Comisión de la Verdad no habían tenido ningún efecto en la práctica y que su aplicación parcial no podía, en términos generales, considerarse una declaración de intención.

Respecto de los "escuadrones de la muerte", la Comisión de la Verdad - pese a contar con muchos elementos de juicio para decir mucho másúnicamente se limitó a recomendar el inicio inmediato de una investigación a fondo, contando con el apoyo de los paises amigos. Pero sólo fue hasta que - consternado por varios asesinatos de dirigentes y activistas del FMLN durante los últimos meses de 1993, al estilo de estos grupos armados ilegales- el secretario Ghali exigió, en noviembre de ese año, el cumplimiento rápido de la recomendación hecha por la Comisión y así se logró, hasta diciembre, la formación del llamado "Grupo Conjunto". El informe del mismo, entregado al final de julio de 1994, fue calificado por monseñor Arturo Rivera y Damas como "una especie de crucigrama"; sus recomendaciones, corrieron la misma suerte que las anteriormente citadas.

\subsection{La Procuraduría para la Defensa de los Derechos Humanos}

El 27 de abril de 1991, como resultado de una de las fases de la negociación entre las partes beligerantes, en México, se acordó realizar ciertas reformas constitucionales. Y mientras en aquel país continuaban debatiendo sobre el nuevo rol institucional de la Fuerza Armada, en El Salvador se realizaban diferentes esfuerzos en torno a las modificaciones a la llamada "Ley Fundamental" del país, principalmente en lo que toca al mecanismo para llevar a cabo cualquier modificación a la misma.

32. Ibid., párrafo 138, p. 50. 
Lo fundamental de dichas reformas tenía que ver con el sometimiento de la Fuerza Armada al poder civil, la creación de un solo cuerpo policial y del organismo de inteligencia estatal, la redefinición de la justicia militar; mejoras al sistema judicial y el establecimiento de mecanismos para garantizar la vigencia de los derechos humanos, así como una nueva definición y organización del sistema electoral. De este bloque de importantes medidas surgieron la PDDH y la PNC.

De esa forma - tras casi un año de haberse firmado el acuerdo de San José- se empezó a gestar la posibilidad de que el Estado asumiese, por fin, su responsabilidad en la protección, promoción y defensa institucional de la dignidad de las personas a través de la institución del Ombudsman. Según la propuesta de reforma constitucional - posteriormente aprobada - dicha figura debía superar la labor realizada in situ por la verificación internacional, al plantearle de manera más explícita su obligación de prevenir toda situación atentatoria a la condición humana de la población salvadoreña. Entre otras cosas debía promover recursos judiciales o administrativos, supervisar la actuación de la administración pública, alentar reformas y emitir dictámenes sobre anteproyectos de ley. Es más: quedó establecido en su ley de creación que no podrían ser aspirantes a procurador "los militares de profesión que estén o hayan estado de alta o quienes pertenezcan o hayan pertenecido a grupos armados de cualquier naturaleza y los que hubiesen sido condenados por violación a los derechos humanos". ${ }^{33}$

Cierto que tanto su ley como su reglamento fueron aprobados en febrero de 1992, anticipándose así a lo establecido en el calendario de ejecución del acuerdo final de paz; más aún: en la elaboración de la primera, la comisión técnica responsable tomó en cuenta una propuesta presentada por diversas organizaciones e instituciones civiles de derechos humanos y no sólo aquella que elaboró la parte oficial. Hasta ahí, las cosas iban bien. Pero, días después, Carlos Mauricio Molina
Fonseca fue elegido procurador; ese hecho no fue el resultado de un análisis objetivo, basado en los criterios más convenientes para el buen desarrollo de la institución sino fruto de una manera de ejercitar el poder en este "nuevo El Salvador": quizás ya no tanto mediante la imposición vertical de las decisiones tomadas en Casa Presidencial sino, principalmente, a través de su distribución o reparto entre los partidos políticos dominantes, por encima del bien común.

De esta forma, siendo la Alianza Republicana Nacionalista (ARENA) y el Partido Demócrata Cristiano (PDC) las dos fracciones mayoritarias en la Asamblea Legislativa se realizó una negociación entre ambas agrupaciones políticas que arrojó como resultado la elección simultánea del Luis Arturo Zaldívar - afín al partido oficial- como presidente del Tribunal Supremo Electoral y del citado Molina Fonseca como máxima autoridad de la Procuraduría, ${ }^{34}$ apoyado por la bancada democristiana. El que éste último no tuviera ninguna trayectoria en la materia y que, más bien, hubiese fungido como viceministro de Trabajo a principios de los años ochenta -época durante la cual se adoptaron medidas lesivas contra el derecho a la organización sindical y se reprimió abierta e indiscriminadamente a la clase trabajadora - fueron elementos que anunciaban la intención de minimizar desde sus inicios la efectividad de la institución. ${ }^{35}$ De ese modo, se presagiaba el futuro de tan importante institución tan sólo como un detalle más de la democracia formal.

Sumado a lo anterior, de manera casi inmediata, miembros del partido en el poder establecieron los límites de la gestión del procurador y de la incidencia de la PDDH. Primero se pusieron trabas económicas a su labor: la retención del financiamiento básico para iniciar, expandir y consolidar su funcionamiento fue evidente, pese a que en la ley se contempló una disposición transitoria para la transferencia de los fondos necesarios mientras se aprobaba el Presupuesto General de la Nación para 1993. Hacia mayo de 1992, el procu-

33. Artículo 6, capítulo II de la ley de creación de la PDDH. Decreto Legislativo No 183 del 20 de febrero de 1992, publicado en El Diario Oficial, No 45, Tomo 314 del 6 de marzo del mismo año.

34. Según la Constitución de la República y la ley de la PDDH, el procurador es elegido por mayoría calificada de los dos tercios de los diputados.

35. La ley de la PDDH establece que uno de los requisitos para ser procurador —quizás el más importante- es el de poseer una "reconocida trayectoria en la promoción, educación y defensa de los derechos humanos" o tener "amplios conocimientos en ese campo". 
rador declaró públicamente que había "suplicado" el otorgamiento de recursos sin obtener respuesta positiva, por lo que comenzó su labor sin contar con local propio y con escasa capacidad de movilización. Esa queja fue reiterada en otras oportunidades.

Al momento de hacer público el anteproyecto de Presupuesto, en septiembre de ese mismo año, se conoció que, mientras al Ministerio de la Defensa Nacional se le seguía concediendo una de las asignaciones más altas -11.35 por ciento del total-, a la PDDH se le había destinado la segunda menor de todas -el 0.14 por ciento- sólo por encima del Tribunal del Servicio Civil. El siguiente año, a la hora de discutir el presupuesto correspondiente a 1994, se conoció que tal porcentaje sería incrementado al 0.22 por ciento del total. A lo anterior se sumó la excesiva y lenta burocracia gubernamental, que -como señaló la PDDH en su memoria de labores correspondiente al período 1992-1993 - hizo menos ágil la dotación de los pocos fondos destinados.

Otra forma utilizada para impedir que la Procuraduría desarrollara efectivamente una labor de impacto en favor de la vigencia de los derechos humanos, fue la de marginarla de asuntos en los que - sin lugar a dudas - debía haber jugado un rol importante. Por citar un ejemplo: tras el fallo de la Corte Internacional de Justicia con sede en La Haya, mediante el cual ciertas extensiones del territorio nacional quedaron bajo la soberanía de Honduras y la población de esos lugares quedó en situación de desprotección, el gobierno salvadoreño no incluyó a la Procuraduría en la comisión binacional para dar seguimiento a la aplicación del fallo.

Desde algunas esferas oficiales también se intentó neutralizar cualquier indicio de credibilidad hacia la Procuraduría, sobre todo cuando - aunque fuese tímidamente- esta institución cuestionaba la actuación estatal en materia de derechos y libertades fundamentales. Al dar a conocer su segundo informe público el 23 de abril de 1993, la PDDH advirtió -entre otras cosas - sobre la configuración de una tendencia en la que destacaba la violación al debido proceso y al derecho a la vida por motivos políticos, exigiendo la investigación correspondiente de parte de las autoridades respectivas así como la celeridad en su erradicación. ${ }^{36}$ Un mes después, el Comisionado Presidencial de Derechos Humanos (CPDH), nombrado el 15 de enero de 1993, difundió ampliamente la existencia de "mejoras en el respeto a la dignidad de los habitantes"; es más, afirmó que las denuncias por violaciones contra los derechos humanos habían disminuido prácticamente a cero y que el Órgano Judicial marchaba bien. ${ }^{37}$

Una lectura se puede hacer de todo lo anterior: la Procuraduría no fue considerada uno de los compromisos prioritarios dentro del cumplimiento del acuerdo de Chapultepec. En realidad, la institución empezó a funcionar gracias al apoyo que le dio la comunidad internacional y a que - al menos desde mediados de 1993 - comenzó a merecer una mayor atención y colaboración de parte de Naciones Unidas, al firmarse un convenio de cooperación mediante el cual ONUSAL se comprometió a trasladarle su experiencia, metodología de investigación y logística. ${ }^{38}$

Pero no sólo políticos y funcionarios interesados en neutralizar la gestión institucional en favor de los derechos humanos fueron responsables de lo que, a fin de cuentas, constituyó un apocado arranque de la PDDH. Así, dentro de ella, se reprodujeron varios de los vicios propios de la tradicional gestión de otras instituciones estatales. En primer lugar, no supo aprovechar en forma adecuada el aporte y la experiencia de las organizaciones e instituciones sociales que -durante los difíciles años de la violencia institucionalizada y la guerra- asumieron con valentía y mucho riesgo la defensa de innumerables personas cuyos derechos y libertades fueron sistemáticamente afectados.

Ello, pese a que tales instancias ofrecieron expresamente su colaboración al señor procurador $y$ algunas, incluso, se involucraron directamente en la capacitación del personal a su cargo; pero la PDDH hizo caso omiso a las propuestas y críticas que recibió de las mismas. En ese marco, pese a que se creó un Consejo Consultivo sugerido por dichas organizaciones e instituciones a fin de con-

36. Diario Latino, 23 de abril de 1993, pp. 16 y 17.

37. Diario Latino, 18 de mayo de 1993, p. 3

38. La Prensa Gráfica, 30 de julio de 1993, p. 3; numeral 94, VIII nforme del director de la división de derechos humanos al secretario general de la ONU, doc.S/26/41/6. 
tar con un espacio de encuentro para discutir y aportar sobre la materia, éste no sólo quedó fuera de la estructura orgánica de la PDDH sino que terminó siendo un ineficiente y nada representativo mecanismo; un espacio desperdiciado, pues no coadyuvó al desarrollo de una labor conjunta entre la institución estatal y la sociedad civil en materia de promoción, protección y defensa de los derechos humanos.

No debe extrañar entonces que las opiniones, críticas y propuestas más importantes sobre determinados hechos o situaciones que de una u otra forma amenazaron con afectar o afectaron la dignidad de las personas, hayan seguido proviniendo de la llamada "sociedad civil" y no de la PDDH. De este modo, fueron las organizaciones e instituciones sociales las que se pronunciaron, por ejemplo, contra la forma cómo se procedió durante el proceso de depuración de la oficialidad castrense y contra la autoamnistía general que se recetaron los responsables de las graves prácticas de violación a los derechos humanos y los crímenes de esa humanidad. ${ }^{39}$

Asimismo - no obstante las consecuencias negativas que podía acarrearles por el manejo publicitario que se hizo para explotar el sentimiento de inseguridad en el que se encontraba la población, producto del creciente fenómeno de violencia delincuencial- se opusieron a la insistente postura del partido ARENA, que buscaba ampliar la aplicación de la pena de muerte en el país. ${ }^{40}$ Pese a ello y a los varios llamados hechos por la ONU, tanto a través de ONUSAL como por medio del experto independiente de su Comisión de Derechos Humanos para que se vinculara con las organizaciones e instituciones civiles de derechos humanos, la PDDH no modificó su actitud.

Desde su instalación, la Procuraduría debió haber enfrentado con energía una lacra que se resistía a ser erradicada: la de los "escuadrones de la muerte" ligados a estructuras policiales —realidad vieja, pero que siguió revelándose en esta etapaamparados en una evidente inoperancia del sistema judicial. Pero tampoco lo hizo; al igual que lo señalado antes, fueron otras instancias las que realmente la denunciaron y encararon.

Cabe decir que la Comisión Interamericana de Derechos Humanos (CIDH) se refirió a la grave situación de los derechos humanos en el país antes del fin de la guerra, cuando dio a conocer -en junio de 1992 - su informe sobre lo sucedido durante $1991 .{ }^{41}$ El Salvador ocupo, en ese entonces, el primer lugar en cuanto al número de casos individuales reportados ante la $\mathrm{CIDH}$; en relación a los mismos, aparecieron como principales responsables miembros de batallones de reacción inmediata, policías nacionales, guardias nacionales, grupos paramilitares y desconocidos vestidos de civil. En otras palabras, en su mayoría, agentes del Estado o vinculados a éste. La Comisión sostuvo que los principales derechos violados habían sido -en orden descendente - el derecho a la vida, a la protección judicial, a la libertad y a la integridad personal; dejó sentado, además, que el gobierno no había cooperado en el esclarecimiento de los hechos al no proporcionar la información pertinente y no cumplir con las recomendaciones hechas por la CIDH.

Esos tres rasgos de la actuación estatal, obviamente, no serían superados automáticamente con la simple suscripción del acuerdo de paz en enero de 1992. Debido a eso la división de derechos humanos de ONUSAL, dentro de su informe correspondiente al período comprendido entre el 1 de mayo y el 30 de junio de 1992, entre otras cosas expresó lo siguiente: "es inquietante la falta de respuesta institucional frente a la protección al derecho a la vida, a la integridad y a la seguridad de la persona. No se han producido progresos significativos en la investigación sistemática de los atentados contra la vida y en la erradicación de las prácticas de intimidaciones y amenazas por parte de grupos clandestinos organizados".

39. "El perdón no se impone por decreto". Carta Abierta dirigida al presidente Alfredo Cristiani, publicada en La Prensa Gráfica el 24 de marzo de 1993 y firmada por la Comisión de Derechos Humanos de El Salvador, el Departamento de Derechos Humanos del Sínodo Luterano Salvadoreño, el Instituto de Derechos Humanos de la UCA y el Socorro Jurídico Cristiano "Monseñor Oscar Romero".

40. Reporte del IDHUCA, "La pena de muerte: problema antes que solución", Proceso, Año 13, No 551 y 552, San Salvador, El Salvador, 1993.

41. Organización de los Estados Americanos, Informe anual de la Comisión Interamericana de Derechos Humanos, 1991. Washington, D.C., Estados Unidos, 1992, pp. 209-214. 
Pero tampoco en ese marco la PDDH hablo y actuó de forma clara y contundente, para imponerse como la institución estatal capaz de enfrentar tan arraigados males. Es más: ni siquiera lo hizo con decisión y valentía cuando uno de sus funcionarios principales, Eduardo Pineda Valenzuela, fue víctima de un atentado criminal que lo dejó inicialmente parapléjico y le provocó la muerte meses después. Este jurista fungió como acusador de la Fiscalía General de la República en el juicio contra los militares acusados de asesinar en la UCA a seis sacerdotes jesuitas y dos de sus colaboradoras. No era aventurado imaginar un posible móvil político en el ataque contra Pineda Valenzuela, con la finalidad de amenazar e inhibir posibles compromisos institucionales que apuntaran hacia la vigencia irrestricta de los derechos humanos.

La PDDH asumió una actitud de indiferencia ante el escabroso proceso de cese al fuego, la endeble "democratización" que se estaba desarrollando en el país -en la que ni siquiera los intentos de golpe de Estado fueron desechados - y otros temas igualmente fundamentales. Por ejemplo: ante la decisión gubernamental de desplegar unidades de la Fuerza Armada a lo largo y ancho del país en labores de seguridad pública, tardíamente el señor procurador se animó a poner en duda la capacidad de los efectivos militares para responsabilizarse de tal tarea en tiempos de paz, ${ }^{42}$ cuando lo que a él le correspondía era hacer un análisis serio en relación a la situación de violencia e inseguridad prevaleciente en el país desde la perspectiva del respeto a los derechos humanos $y$, lógicamente, proponer soluciones viables dentro de las cuales no debía descartarse — de entrada y por simples prejuicios - la participación de efectivos militares, siempre y cuando ésta se diera bajo la dirección de la PNC y con la supervisión de la PDDH.

Sin duda, fueron numerosos los llamados para que la Procuraduría asumiera un papel de liderazgo y generase confianza entre la población. Comenzaron incluso desde antes que la institución imumpiera en la vida nacional; provinieron, sobre todo, de entidades civiles de derechos humanos nacionales e internacionales. ${ }^{43}$ Pero el señor procurador no pasó de dedicarse solamente a las simples formalidades, inaugurando oficinas de la PDDH en el interior del país y emitiendo únicamente juicios tibios sobre la situación, a sabiendas de que uno de los mayores retos para garantizar la construcción de un verdadero Estado democrático y participativo de Derecho era el de romper con el inveterado patrón de impunidad, propiciado y perpetuado por instancias estatales, tal como lo señaló Pedro Nikken en el último informe que presentó en su calidad de experto independiente de la ONU encargado del caso salvadoreño. Fatal deficiencia la del primer Ombudsman nacional, a la que se sumó el que muchas de sus recomendaciones no apuntaran a erradicar las prácticas de violación de los derechos humanos, sino tan sólo a sugerir medidas cuya negligente superficialidad era evidente.

$\mathrm{Y}$ no es que se menosprecie que aconsejara la formación en derechos humanos para agentes policiales y militares, ante su recurrencia en la violación de los mismos; lo peligrosamente errado era que aunque acciones de este tipo terminaran hasta en la muerte de las víctimas, ni siquiera entonces la PDDH - fuera de alguna muy rara excepción- exigía con fuerza investigaciones exhaustivas, enjuiciamiento y sanciones para los responsables, no obstante estar legalmente obligado a ello. Esa tendencia no se dio sólo en su primer informe, sino en el segundo y el tercero, en su memoria de labores y en el último documento que elaboró. Es más: hubo casos graves en los que no se hizo recomendación alguna pese a haberse comprobado las violaciones, sobre todo cuando los responsables identificados fueron comandantes, agentes policiales, jefes militares o, incluso, jueces.

Sus gestiones para promover la vigencia de los derechos humanos en otros aspectos, también fueron prácticamente nulas. Vinieron a ser otros los que demandaron con insistencia, por ejemplo, la creación por parte del gobierno de un fondo de reparación material para las víctimas de la violencia o contra sus familias. La Arquidiócesis de San Salvador así lo hizo y la Comisión de Derechos Humanos de El Salvador presentó un anteproyecto de ley a la Asamblea Legislativa, con el propósito de concretar dicha iniciativa.

El señor procurador formó parte del "Grupo Conjunto", creado para investigar el funciona-

42. La Prensa Gráfica, 9 de julio de 1993, p. 54

43. Reporte del IDHUCA. "El informe de Americas Watch", Proceso, Año 13, No 531, San Salvador, El Salvador, 1992, p. 13. 
miento de los "escuadrones de la muerte" después de la guerra. Para algunos observadores y analistas, esa fue la experiencia más destacada de su gestión al frente de la institución. Para otros, no fue muy satisfactoria dentro de su labor no se consideró a las víctimas anónimas que diariamente cobraba la violencia que continuó produciéndose con la anuencia, tolerancia o connivencia del Estado. Antes de la creación del "Grupo Conjunto" ocurrida sólo hasta que connotados dirigentes del FMLN fueron asesinados a finales de 1993 - se escucharon algunas voces institucionales advirtiendo sobre el peligro que acechaba al proceso electoral en ciemes; únicamente entonces, el señor procurador se animó a pedir erradicar la impunidad y solicitar que el Estado realizara un esfuerzo coordinando entre la Policía Nacional Civil, la Fiscalía General de la República y la PDDH, al que se debían sumar los sectores políticos, independientes e internacionales; por cierto y para ilustrar el nivel de impacto de su gestión, el gobiemo ignoró totalmente su recomendación y apenas comenzó a considerar el tema tras la fuerte presión del secretario general de la ONU.

\section{Amnistía e impunidad: antítesis de la ver- dad y la justicia}

En El Salvador se cometieron innumerables y graves infracciones a las normas vigentes del derecho internacional de los derechos humanos y del derecho internacional humanitario. Muchas de ellas configuran crímenes intemacionales, aberrantes y particularmente repudiables. La Fuerza Armada, los cuerpos de seguridad y los grupos paramilitares se encargaron de realizar innumerables actos de violación al derecho a la vida, a la integridad física, a la libertad y a la seguridad personal. En menor proporción, pero no por ello menos reprochable, los insurgentes también cometieron actos contrarios a la dignidad humana, al llevar a cabo hechos tipificados como crímenes de guerra. Pero no se hizo justicia. Los infractores de toda la normatividad se auto amnistiaron para no saldar la cuenta que tenían y aún tienen con toda la sociedad.

Ante esta realidad, el establecimiento de las condiciones para alcanzar un clima de verdadero respeto a los derechos humanos, se convirtió en uno de los ejes principales de la búsqueda y el logro de la paz. No es fortuito que como resultado de los compromisos surgidos de las negociaciones, se haya definido una serie de medidas tendientes a erradicar las estructuras de represión y a superar la impunidad. De ahí el establecimiento de ONUSAL, la creación de la PDDH y la PNC, el funcionamiento de la Comisión de la Verdad, la desaparición de los antiguos cuerpos de seguridad y los grupos paramilitares, y la reducción de la Fuerza Armada.

Pero, además, había que dar cumplimiento a normas convencionales así como otras contenidas en resoluciones de la ONU y en las mismas legislaciones internas de los Estados, que contemplan la obligación del ejercicio de la acción penal por parte de éstos, investigando y sancionando a los responsables de crímenes, a la vez que mandan otogar reparación del daño a la víctima o a sus familiares, ya sea a través de la reivindicación moral o la compensación económica. De igual forma, en el derecho aplicable en situaciones de conflictos armados internos se establecen sanciones a los actores de la guerra que realizan acciones contra la población civil no combatiente y contra combatientes fuera de combate por prisión o heridas, acciones catalogadas como "crimenes de guerra".

En ese sentido, el relator especial de Naciones Unidas para el problema de las Amnistías, Louis Joinet, sostiene la invalidez o improcedencia de la "amnistía recíproca" frente al derecho intemacional en situaciones de conflicto amado sin carácter internacional, ya que con ella se "tiende esencialmente a organizar la impunidad de los agentes estatales o paraestatales, autores de graves atentados a la dignidad humana". Joinet sostiene además muy atinadamente - que "el poder amnistiante no se contenta con asegurar, por ejemplo, la impunidad penal de los torturadores, sino que busca por otra parte organizar la conspiración de silencio que impida toda posibilidad para las víctimas de obtener las reparaciones materiales, e incluso morales, a las que pueden aspirar según el derecho común. El fin buscado es menos evitar una sanción civil, tal como el pago eventual de una indemnización reparadora, como suprimir toda posibilidad de investigación que pueda dar lugar a publicidad con ocasión del proceso civil, lo que confirma una vez más que la publicidad es la sanción más temida por los autores de graves atentados a la condición humana".

De las cuatro amnistías decretadas en el marco del conflicto armado salvadoreño, al menos tres de ellas pueden enmarcarse en la pretensión del "bo- 
món y cuenta nueva". Esto - lastimosamente- se tradujo en una luz verde a los criminales quienes, alentados por ese clima de impunidad, continuaron violando derechos fundamentales de la población al margen de la ley. Pero también, con la impunidad -entendida ésta como la falta de castigohoy se siguen violando una serie de derechos humanos a las víctimas de la violencia pasada, principalmente el derecho al reconocimiento de la personalidad jurídica, el derecho a la igualdad ante la ley, el derecho a un recurso judicial efectivo, el derecho a un juicio justo, el derecho al conocimiento de la verdad de los hechos y la identidad de los responsables.

Jurídica y moralmente, es inaceptable que las autoamnistías decretadas enmarquen de manera general un conjunto de delitos, además de los políticos propiamente dichos, ya que se incluyen en ellas - no obstante los señalamientos de inconstitucionalidad- delitos comunes cometidos por cualquier persona con motivo o en razón del conflicto armado, o por grupos de veinte a más personas. Peor aún, el Estado extingue la responsabilidad civil para todos los casos amnistiados, en claro atropello a la Constitución de la República, a la legislación internacional y al mismo Código Penal. Es obvia la pretensión oficial de marginar de la justicia a las víctimas.

Estas amnistías sólo favorecen la impunidad ya que han sido promulgadas sin conocer previamente la verdad sobre los hechos y sobre los violadores; se dictan antes que haya un proceso para deslindar responsabilidades. Se impone el perdón oficial, antes que la víctima o los afectados lo expresen; se impone el perdón sin el arrepentimiento de los criminales. Claro está que también resulta inadmisible una amnistía inmediatamente después del juicio contra los criminales, aunque en este caso se haya "hecho justicia", pues existen crimenes que no son amnistiables por su propia naturaleza. Para el caso, baste citar la resolución de la Comisión Interamericana de Derechos Humanos con respecto a la amnistía de 1987 , específicamente en lo concemiente a la exculpación de oficiales y soldados del ejército junto a miembros de la "defensa civil", quienes el 22 de febrero de 1983 asesinaron a 74 campesinos en Las Hojas, departamento de Sonsonate.

La Comisión consideró que tales hechos constituían una violación de los derechos consagrados en la Convención Americana y que el gobierno había dejado de cumplir la obligación impuesta en el artículo 1 de la misma, que manda garantizar el libre y pleno ejercicio de los derechos y garantías fundamentales. En este caso - sostuvo la Comisión- con la amnistía se cerró la posibilidad de una investigación efectiva del caso $\mathrm{y}$, consecuentemente, el castigo de los responsables así como el logro de una adecuada compensación a las víctimas y a sus parientes cercanos.

Se dijo entonces, además, que el artículo 27 de la Convención de Viena sobre el derecho de los tratados establece que un Estado no puede invocar su derecho intemo como justificante para el incumplimiento de un tratado. Si bien un Estado es soberano para decretar una amnistía, cuando ésta impide a los afectados por los delitos amnistiados acceder a la justicia en el reclamo de sus derechos el caso ya no sólo compete a la jurisdicción interna.

Las amnistías ciertamente tienen como objetivo fundamental e intrínseco otorgar el perdón y el olvido a quienes en circunstancias sociales o políticas extraordinarias cometieron delitos y atentados que en alguna medida conmovieron a la sociedad. Pero no es aceptable $-y$ así lo estatuyen el derecho internacional y la doctrina de los derechos humanos - que las amnistías dadas en un marco de grave violación a los derechos fundamentales de la población, eximan de toda responsabilidad penal a quienes no han sido llevados ante la justicia por sus delitos o perdonen hechos que aún no han sido esclarecidos y juzgados. La doctrina y las normas jurídicas tampoco permiten librar de su responsabilidad civil a una persona responsable de esos delitos. Sin embargo, la historia y la política en El Salvador han contrariado y atropellado la más elemental lógica jurídica o moral, al aprobar amnistías que toleran a los más impunes delincuentes.

Con la etapa iniciada después del fin de la guerra se pretende, entre otras cosas, la convivencia armónica y pacífica de la sociedad. En ella se busca establecer las bases para una verdadera democracia. Una de esas bases debe ser la erradicación de la impunidad, ya que sin esa no se puede hablar de lo otro. $Y$ es que la impunidad representa una situación por el cual el Estado renuncia concientemente a su obligación de administrar y hacer justicia; una situación mediante la cual se tolera, encubre y realiza el atropello de la ley. La impunidad —en tanto negación absoluta de justicia- se considera como violencia política, como instru- 
mento de un Estado terrorista que oculta sus crímenes a través de ella.

Pero en El Salvador, los responsables de aberrantes crímenes contra la población civil hasta disfrutan y gozan de jugosas indemnizaciones y pensiones que el Estado les ha otorgado. Los responsables de las graves violaciones a los derechos humanos $y$ al derecho internacional humanitario sostienen, ufanos, que hicieron uso de la institución armada para defender al país de ideologías extrañas. No se trata de cuestionar en sí el conflicto armado, sino aquellos hechos que fueron más allá del límite; más allá de las acciones puramente militares contra el enemigo armado. Igualmente cuestionable y condenable es la lucha insurreccional, cuando al amparo de su legitimidad -incluso reconocida como un derecho- se secuestra y asesina a una persona indefensa o no se miden los alcances en ataques a guarniciones militares ubicadas en medio de poblaciones y de las cuales se derivan víctimas civiles; también éstas son acciones repudiables que no tienen ninguna justificación.

Las investigaciones realizadas por la Comisión de la Verdad y el "Grupo Conjunto" así como los informes y recomendaciones que ambas instancias emitieron al concluir su mandato, constituyeron en un primer momento- un esperanzador pórtico por donde se empezaba a vislumbrar la posibilidad de llegar a la verdad sobre aquellos hechos y permitir a la sociedad salvadoreña concretar la tan anhelada justicia que miles de ciudadanos esperaron por tanto tiempo. Sin embargo, pese al arduo esfuerzo y los serios riesgos que corrieron los investigadores y decenas de testigos ante los sectores que pretendían acallar las voces de verdad y justicia, al final resultaron vanas las esperanzas debido al encubrimiento que obstaculizó jurídica y políticamente toda medida que pudiera concretar el enjuiciamiento de los criminales y los comuptos.

Cinco días después de la presentación oficial del informe de la Comisión de la Verdad ante el secretario general de las Naciones Unidas, el 20 de marzo de 1993, la mayoría de diputados de derecha - representados en la Asamblea Legislativa por 47 elementos en total del gobernante partido ARENA, del Partido de Conciliación Nacional (PCN) y del Movimiento Auténtico Cristiano (MAC) - aprobó el Decreto No 486, conocido como Ley de Amnistía General para la Consolidación de la Paz.
Este baldazo de agua fría lanzado contra las estupefactas familias de las víctimas de los crímenes cometidos en la guerra y contra las mismas víctimas, vivas o muertas, significó la más cruel burla que habría de darse a las personas más sufridas y a quienes habían creído firmemente que los cambios que el proceso de paz contemplaba podían significar - de una vez por todas - la inauguración de una nueva etapa para el país y sus habitantes.

Cuatro organizaciones civiles de derechos humanos se pronunciaron públicamente contra la medida en el XIII aniversario de la muerte de Monseñor Romero, de esta manera: “(...) con la recién aprobada amnistía general se pretende imponer un olvido fácil sobre las atrocidades vividas y liberar de culpa a los responsables de asesinatos, capturas, desapariciones y torturas, sin que se conozca su participación en esos delitos y se les aplique la justicia. Tal actitud es absolutamente farisaica, cuando proviene de los mismos sectores que exigen la reimplantación de la pena de muerte contra aquellas personas que, sin negar su participación en hechos intolerables que merecen ser sancionados justamente, se ven orillados a delinquir por un sistema que les impide el disfrute de los niveles mínimos de subsistencia. Contradictoriamente, quienes incurrieron en graves violaciones a los derechos humanos y crímenes de lesa humanidad, quieren continuar impunes".

Ante eso y la situación de violencia, inseguridad y temor que prevalecen en el país, se debe privilegiar hoy en día el rescate de la memoria de las víctimas, la exigencia de la verdad ampliada, el paradero de las personas desaparecidas, la aplicación de la justicia, las reparaciones morales y económicas para las víctimas o sus familiares. Todo ello constituirá el legado nacional para que las conciencias, apaciguadas, puedan finalmente perdonar y para evitar que una explosión similar o peor que la del pasado se repita.

\section{Conclusión}

El origen último del conflicto armado se debe buscar en causas estructurales sostenidas por un andamiaje institucional que ha fomentado y mantenido la marginación social, la opresión económica y la represión político-militar contra las mayorías; es decir, en la sistemática negación de los derechos civiles, políticos, económicos y sociales de la gran mayoría de la población salvadoreña. 
Los regímenes militares dictatoriales, impuestos a través de golpes de Estado o fraudes electorales, en indisoluble alianza con enormes intereses económicos, desarrollaron progresivamente una política de autoritarismo militar y sometimiento social, en la cual las aspiraciones democráticas de grandes sectores nacionales se vieron frustradas y relegadas. Las luchas por reivindicaciones sociales y mejores condiciones de vida fueron tildadas de subversivas y reprimidas; las capturas arbitrarias, la tortura, el asesinato por supuestas o reales filiaciones políticas, la desaparición forzosa de personas, el secuestro, las amenazas, los desplazamientos y ataques a la población civil, el exilio y la difamación, caracterizaron este período de la historia nacional.

El efecto del cierre de espacios democráticos de participación y de la opresión ejercida por aquellos poderosos sectores económicos comenzó a observarse con el surgimiento de fuerzas sociales organizadas y grupos insurgentes armados que propugnaban cambios democráticos en la estructura vigente, llevando a la Nación entera a niveles de polarización nunca vistos, hasta desembocar en el conflicto armado.

Decenas de miles de personas fueron asesinadas impunemente, tanto de manera individual como colectiva. Otras miles, la mayoria civiles, fueron desaparecidas después de haber sido capturadas ilegalmente por autoridades. Antes de que se declarara el estado de guerra, los cuerpos de seguridad y las Fuerzas Armadas realizaron de modo sistemático innumerables detenciones arbitrarias y -en la gran mayoría de los casos- recurrieron a la práctica de la tortura y tratos crueles, inhumanos y degradantes contra las víctimas. En claras infracciones a las disposiciones del derecho internacional humanitario, la institución castrense incumplió las normas aplicables en situaciones de conflicto armado interno y sus efectivos actuaron, de manera arbitraria y prepotente, sin ningún control legal o judicial.

Los grupos armados ilegales conocidos como "escuadrones de la muerte", llevaron a cabo su táctica de exterminio en contra de sectores organizados de la sociedad vinculados al movimiento popular. Amparados por la complicidad de esferas gubernamentales, estos grupos asesinaron con lujo de barbarie, torturaron y desaparecieron a miles de personas sin que nunca se iniciara un proceso de investigación en torno a horrorosos he- chos que impactaron a la sociedad.

Mientras ello sucedía, el Órgano Judicial y el Ministerio Público lejos de cumplir con su objetivo fundamental de velar por la impartición de justicia, investigando y sancionando las violaciones a los derechos fundamentales de los habitantes del país, se convirtieron en una pieza más del modelo contrainsurgente del Estado.

Durante el desarrollo de la guerra, los alzados en armas también incurrieron en una serie de infracciones al derecho aplicable en los conflictos armados, cometiendo numerosos atropellos contra la población civil que residía en las zonas de combate o sus alrededores. Miembros de la insurgencia realizaron ejecuciones sumarias de funcionarios públicos, jefes de gobiernos locales, "espías" y delatores, elementos de las tropas gubernamentales y supuestos o reales "traidores" a su causa. En no pocas ocasiones las acciones militares de los rebeldes se caracterizaron por los secuestros $y$ extorsiones, en claras infracciones al derecho internacional humanitario.

Al final, sin embargo, los elevados niveles de violación a los derechos humanos que ocurrieron en el país durante el desarrollo de la guerra fueron un elemento catalizador —entre otros de carácter político- que motivó a que la comunidad internacional ejerciera mayor presión a las partes enfrentadas, ante el empantanamiento militar, y se buscara una solución negociada. Así se abrió la oportunidad de trascender en pasos positivos hacia una nueva etapa histórica para el país. Con el acuerdo de Chapultepec se establecieron las nuevas condiciones políticas, bajo las cuales las partes intentarían darle un giro sustancial a la institucionalidad de la Nación. Sin embargo, el proceso para consolidar la paz mediante la ejecución de los compromisos no se dio con un acatamiento lineal y estricto de lo acordado; lastimosamente, tampoco permitió el rompimiento de las barreras que habían significado en el pasado la fuente de innumerables arbitrariedades.

La desnaturalización de los compromisos originales destinados al rediseño institucional fue realizada a veces en forma abierta; otras de manera sutil, restringida apenas por los límites excesivamente tolerantes que imponía la verificación internacional. Pese a ello, dicha desnaturalización no dejó de ser notoria, sobre todo por sus fatales consecuencias en la vida cotidiana: se siguieron co- 
metiendo - aunque en menor cuantía- abusos graves y la tibieza estatal fue incapaz de revertir la perpetuación de la violencia. Algo propio de este proceso fue el hecho de que la creación de las nuevas instituciones dependió fundamentalmente del apoyo político, diplomático, material y financiero de otros países.

Maniobrando, sectores o grupos interesados en seguir "remando contra corriente" no permitieron y aún sigue impidiendo la real irrupción de la nueva institucionalidad y de la consciente participación de la población. Esto, unido a la permanencia de una estructura económica y social injusta, que cada día ahonda más la brecha entre los inmensamente ricos y los progresivamente menesterosos, le colocan serios signos de interrogación al futuro.

Para vislumbrar, pues, un porvenir más esperanzador para El Salvador es necesario seguir trabajando por la transformación de las actuales estructuras que impiden garantizar el pleno respeto de los derechos fundamentales de las mayorías, en el espíritu de Chapultepec. Si bien —al pacificarse el país - las violaciones sistemáticas y masivas a los derechos civiles y políticos presentan una notable reducción, ahora - aún más que durante la guerra- los derechos económicos, sociales y cul- turales distan de verse sustancialmente mejorados. Las raíces originarias del conflicto armado persisten en la actualidad y la mayoría de la población salvadoreña se debate en la extrema pobreza.

Mientras esto siga siendo así, la paz y el bienestar no habrán pasado de ser un mito, un espejismo que la angustia de tantos años de sufrimiento y el dolor de las miles de víctimas heredadas dibujaron en el cerebro de millones de ilusionados salvadoreños y salvadoreñas.

A las organizaciones civiles de derechos humanos les seguirá correspondiendo un importante papel en este esfuerzo por hacer realidad tantas aspiraciones no cumplidas, ya que son ellas las fuerzas de la sociedad llamadas a participar activamente - acompañando a las víctimas y sus familiares - en el tránsito hacia la verdad, la justicia y la vigencia de los derechos fundamentales para las mayorías. Porque la ausencia de justicia incentiva a los criminales a continuar con las violaciones y amenazas a la seguridad e integridad física de los más débiles y de los cuestionadores de la opresión. Sólo mediante la erradicación de la impunidad y la injusticia social, El Salvador estará en la posibilidad de garantizar que ese pasado reciente, doloroso y triste, nunca más vuelva a repetirse. 